Review

\title{
Hybrids of Nucleic Acids and Carbon Nanotubes for Nanobiotechnology
}

\section{Kazuo Umemura}

Biophysics Section, Department of Physics, Tokyo University of Science, 1-3 Kagurazaka, Shinjuku, Tokyo 1628601, Japan; E-Mail: meicun2006@163.com; Tel.: +81-352288228

Academic Editor: Stephen Ralph

Received: 22 January 2015 / Accepted: 5 March 2015 / Published: 12 March 2015

\begin{abstract}
Recent progress in the combination of nucleic acids and carbon nanotubes (CNTs) has been briefly reviewed here. Since discovering the hybridization phenomenon of DNA molecules and CNTs in 2003, a large amount of fundamental and applied research has been carried out. Among thousands of papers published since 2003, approximately 240 papers focused on biological applications were selected and categorized based on the types of nucleic acids used, but not the types of CNTs. This survey revealed that the hybridization phenomenon is strongly affected by various factors, such as DNA sequences, and for this reason, fundamental studies on the hybridization phenomenon are important. Additionally, many research groups have proposed numerous practical applications, such as nanobiosensors. The goal of this review is to provide perspective on biological applications using hybrids of nucleic acids and CNTs.
\end{abstract}

Keywords: single-stranded DNA; double-stranded DNA; RNA; carbon nanotubes (CNTs); functionalization

\section{Introduction}

The hybridization of DNA and carbon nanotubes (CNTs) was first reported in 2003 when Zheng et al. presented the hybridization of single-stranded DNA (ssDNA) and single-walled carbon nanotubes (SWNTs) [1]. They not only presented experimental data, but also introduced a theoretical model of the adsorption of DNA onto SWNT surfaces (Figure 1). Furthermore, this work suggested there is a correlation between specific bases of DNA molecules and SWNT chirality. Nakashima et al. independently described the solubility of SWNTs with DNA molecules in 2003 [2] using double-stranded 
DNA (dsDNA) molecules. Thereafter, many research groups have reported on the hybridization of DNA and CNTs, especially SWNTs.
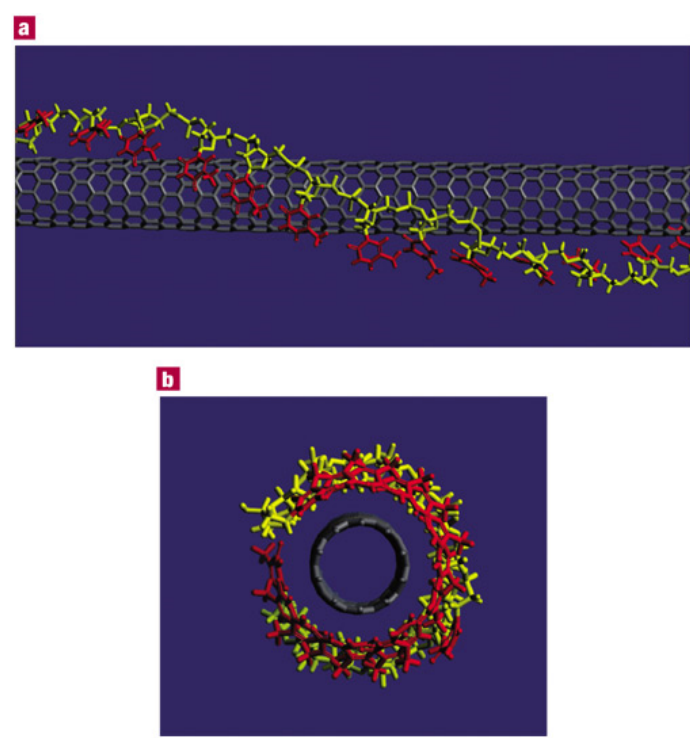

Figure 1. A theoretical model of structure of single-stranded DNA (ssDNA) and single-walled carbon nanotubes (SWNTs) hybrids, proposed by Zheng et al. $(10,0)$ SWNT and poly(T) were assumed for the calculation (Reprinted from reference [1] with permission).

There have been two central hybridization research goals since 2003 . The first is to improve the solubility of CNTs. Although the unique structural and physicochemical properties of CNTs are appealing for fundamental and industrial applications, uncoated CNTs typically form insoluble bundles in aqueous solutions. To take full advantage of CNTs, they must be prepared in a mono-dispersed form, which is especially true for SWNTs. Mono-dispersed CNTs can be prepared with attached hydrophilic organic molecules, such as sodium dodecyl sulfate (SDS), peptides, proteins, or DNA molecules, which can enhance CNT solubility. Another goal of hybridization is to purify SWNTs. SWNTs exhibit chirality, which is determined by the chirality vector, $C_{h}=n a_{1}+m a_{2}$. The $a_{1}$ and $a_{2}$ variables represent unit vectors on a graphene surface, and $n$ and $m$ are integers. Physical properties of SWNTs, such as electrical and optical characteristics, can vary depending on chirality. Because the chirality of SWNTs cannot be well controlled during synthesis, post-synthesis purification is required for some SWNTs for industrial applications. These two objectives were the main rationales for initial studies on hybridization.

While the method for DNA adsorption onto CNTs was originally developed to solubilize and purify CNTs, DNA-CNT hybrids also have great potential as DNA nanodevices. In this review, the fundamental studies of DNA and CNT hybridization for biological applications, especially in solutions, will be presented. Modification of electrode surfaces with DNA and CNTs is another major area of research; however, this topic will be explored elsewhere.

\section{Non-Covalent Hybridization of DNA Molecules onto SWNT Surfaces}

The solubility of CNTs is a major area of CNT research, with the aim of preparing mono-dispersed CNT suspensions. Prior to using DNA, various organic molecules were employed to hybridize with CNTs [3-18]. Although this article focuses on DNA technology, several examples of hybridization using 
other molecules are introduced for comparison. Various organic molecules, such as polyvinyl pyrrolidone (PVP) and polystyrene sulfonate (PSS) [3], poly(propionylethylenimine-co-ethylenimine) [5], hyperbranched polymers [6], 12-membered cyclodextrins [7], SDS [8], Nafion [10], poly( $N$-cetyl-4-vinylpyridinium bromide-co- $N$-ethyl-4-vinylpyridinium bromideco-4-vinylpyridine) [14], and electroactive methylene blue (MB) dyes [15] have been employed. Polysaccharides, such as lactose-appended schizophyllan [12] and $N$-trimethyl-chitosan [17], have also been used to control the electrical properties of prepared hybrids. Furthermore, proteins such as bovine serum albumin (BSA) [4] have been employed to solubilize both SWNTs and multiple-walled CNTs (MWNTs). Early reports suggested the possibility of separating specific CNTs using surface modification.

Numerous review articles have been published on the subject of solubilization [19-38]. At present, the review titled "Advances toward Bioapplications of Carbon Nanotubes" and prepared by Lin et al. in 2004 has been cited over 500 times [24]. Although this review described examples of solubilization studies using various organic molecules, only a few studies illustrating the relationship between DNA and CNTs existed before 2004 because the review was written at the early stages of research on DNA and CNT hybridization. Since 2005, several review articles that have focused on DNA applications with CNTs have been published [25,27,29-32,34-36,38].

In 2014, The Web of Science database contained approximately 4000 studies with both the keywords "DNA" and "carbon nanotube". Among these, approximately 1000 were reports on suspensions or solutions. In this review, approximately 240 papers were selected that focus on biological applications. First, the fundamental studies of hybridization are reviewed [39-79]. The articles are divided into categories based solely on the types of nucleic acid molecules used.

Interestingly, although some of the articles provided detailed information on the DNA molecules that were used in the experiments, some of them did not include details on the DNA molecules. If the types of the employed DNA molecules were important factors for the research, the authors would likely have described them in detail. However, if the DNA molecules were merely one of the organic molecules used to solubilize CNTs, detailed descriptions might not be necessary. A researcher's stance on DNA-CNT hybrids is apparent based on the description of DNA in an article.

\section{Hybridization with dsDNA}

A large portion of hybridization research uses double-stranded DNA molecules, including DNA from salmon testes [2,39,54,67,70,72], calf thymus [74,76,79], or fish sperm [75]. These commercially available DNA molecules are suitable for industrial applications because their cost is less than that of synthesized ones. At the initial stages of hybridization research, finding optimal hybridization conditions was one of the major aims. Barisci et al. proposed that a $1 \%$ SWNT suspension could be prepared with DNA molecules [39]. Characterization of the prepared DNA-CNT hybrids was the next area of study. Badaire et al. measured the average length and diameter of the hybrids using dynamic light scattering [40]. Cathcart et al. reported an increase in the photoluminescence intensity of SWNTs with decreasing concentrations of SWNTs [54].

Several applications for DNA-CNT hybrids have been reported. Asada et al. fabricated thin-film transistors (TFTs) using dsDNA-SWNT hybrids [67]. Wang et al. prepared transparent conductive films 
on PET substrates [70]. Wang et al. modified a glassy carbon electrode with dsDNA-SWNT hybrids and Nafion composites [75].

Although the hybridization method is essentially well established, the search for optimal hybridization conditions is ongoing. Chhikara et al. established that cationic cholesterol induces higher stability in DNA-SWNT hybrids [74]. Ao et al. reported cholesteric and nematic liquid crystalline phase behavior of SWNTs with dsDNA [72]. Primo et al. dispersed bamboo-like multi-walled carbon nanotubes (bCNTs) for the modification of glassy carbon electrodes [76]. Recently, Tardani et al. demonstrated the hybridization in a nematic phase of dsDNA-water- $\mathrm{NaCl}$ [79]. These reports suggest that optimal conditions of the hybridization are easily changed according to types of DNA/CNT and concentrations of DNA/CNT mixtures.

As described above, various fundamental and applied studies have been reported using natural dsDNA molecules. Variation of dsDNA molecules revealed huge potential for industrial applications. However, the mechanisms of hybridization between dsDNA and CNTs are currently not well understood. Fundamental research clarifying the details of dsDNA-CNT hybrids is necessary. Furthermore, many studies do not identify the sequences of dsDNA molecules used. Examining the effects of the sequence of dsDNA used could be a focus of future study.

\section{Hybridization with ssDNA}

Hybridization of ssDNA and CNTs has also been demonstrated. In most cases, synthesized oligonucleotides were utilized. Because Zheng et al. reported that the 30-m of thymine $\left(\mathrm{T}_{30}\right)$ resulted in the highest yield of hybridization, oligonucleotides containing thymine have been widely employed.

$\mathrm{Hu}$ et al. used (GT) 15 and achieved selective and sensitive detection in the form of quasi-reversible voltammetric responses [43]. Bertoncini et al. employed a poly (GT) 15 sequence to confirm the debundling of SWNTs [53]. Haggenmueller et al. compared (GT) $)_{15},(\mathrm{GT})_{10},(\mathrm{AC})_{15},(\mathrm{AC}) 10$, and $\mathrm{C}_{10-30}$ as well as surfactants and other biomolecules in hybridization [61]. Hughes et al. used $\mathrm{A}_{15}, \mathrm{G}_{15}, \mathrm{C}_{15}$, and $\mathrm{T}_{15}$ to disperse CNTs and found that the order of dispersion efficiency was $\mathrm{T}>\mathrm{C}>\mathrm{G}>>\mathrm{A}$, and that the adsorption speed of cytosine was the fastest [68].

The use of synthesized ssDNA molecules enabled detailed characterization of the physical and chemical properties of the prepared hybrids. Fagan et al. used the 30-m 5'-GT(GT)13GT-3' to investigate the effects of $\mathrm{pH}$ on hybrid properties [46]. Jin et al. used (GT) $15,(\mathrm{GC})_{15}$, and 5'-TAG CTA TGG AAT TCC TCG TAG GCA-3' to detect the transition phenomenon between 0 and $50{ }^{\circ} \mathrm{C}$ [58]. Cooper et al. debundled double-walled CNTs (DWNTs) using ssDNA and evaluated the DWNTs using cyclic voltammograms [63]. Ghosh et al. utilized ssDNA, such as (GT)40, to disperse MWNTs while studying thermal ablation [64]. Jovanovic et al. used gamma-irradiation for hybridization instead of sonication [65]. Qiu et al. used (GT) 20 and investigated electrostatically driven interactions using force-distance curves [77].

Throughout, technical progress has been reported. Chen et al. demonstrated controlled precipitation using $\mathrm{T}_{30}$ [45]. Onoa et al. fabricated a field effect transistor (FET) with poly(CT) and SWNTs [51]. Zhao et al. hybridized SWNTs with long ssDNA molecules synthesized by rolling circle amplification [52]. Han et al. used (GT) ${ }_{29} \mathrm{SH}$ for hybridization with SWNTs and attached Au nanoparticles to the prepared hybrids [55]. Hopkins et al. demonstrated the alignment of ssDNA-SWNT 
hybrids using an inkjet printing method [56]. Pease et al. investigated the length distribution of SWNTs using electrospray differential mobility analysis (ES-DMA).

Short ssDNA molecules with user-specified lengths and sequences can be easily synthesized. Therefore, comparative studies using multiple combinations have been reported for understanding the hybridization mechanism. In addition, examination of assorted combinations can be used to obtain clues for sorting and purifying CNTs. The focus of many of the studies using synthesized ssDNA molecules was closer to chemistry than to biology. Further work from the viewpoint of biology and biotechnology are anticipated in the near future.

\section{Comparative Studies Using ssDNA, dsDNA, and Other Nucleic Acids}

Investigations comparing ssDNA, dsDNA, and other nucleic acids are also popular approaches to studying hybridization. He et al. deposited calf thymus dsDNA, calf thymus ssDNA, poly(G), or poly(diallyldimethylammonium) (PDDA) on water-soluble oxidized SWNTs to generate DNA sensors [41]. Yan et al. compared the hybridization of MWNTs with either calf thymus ssDNA or dsDNA using cyclic voltammetry [44]. Gigliotti et al. found that long genomic ssDNA molecules formed tight helices around CNTs [47]. Gladchenko discussed the behaviors of double-stranded and single-stranded regions of ultrasonically examined dsDNA present in the hybrid [48]. Vogel et al. examined $(\mathrm{GT})_{n}$ and $(\mathrm{AC})_{n}$ with $n=2,3,5,10,20$, or 40 to find the optimum conditions for hybridization [59]. Yamamoto et al. used short dsDNA molecules, $\mathrm{A}_{20} / \mathrm{T}_{20}$, as well as $\mathrm{A}_{20}$ and $\mathrm{T}_{20}$ to purify highly stable hybrids by chromatography [71].

RNA molecules were examined by several researchers. Ishibashi et al. employed RNA molecules, $\operatorname{poly}(\mathrm{A})$, poly $(\mathrm{C})$, and $\operatorname{poly}(\mathrm{G})$ to prepare RNA-SWNT hybrids, and fabricated multilayer films using the layer-by-layer technique [50]. Sanz et al. hybridized RNA molecules from baker's yeast with SWNTs, DWNTs, and MWNTs for use in gene delivery systems [73].

There are unique approaches using specific molecules that are related to DNA or RNA. Ikeda et al. prepared SWNT hybrids with adenosine triphosphate (ATP) and other related molecules using a high-speed vibration milling technique [49]. Schmucker modified DNA molecules with pyrene and prepared DNA-SWNT hybrids in 2013, revealing that DNA modification affected the solubilization and photoluminescence of SWNTs [78].

Comparative studies using both ssDNA and dsDNA molecules are attractive to illuminate the differences of the nucleic acid structures on CNT surfaces. When naturally derived long dsDNA molecules are employed, preparation of ssDNA molecules that have similar length and similar sequence is not easy. When dsDNA molecules are synthesized using hybridization of two short synthesized ssDNA molecules, residual ssDNA molecules should be considered. The use of well-purified ssDNA and dsDNA molecules that are 500 to 1000 bp long and have similar sequences could be an interesting area of research. There are not many examples of hybridization of RNA and other nucleic acids with CNTs. The use of various nucleic acids with diverse physical properties is an attractive target in biophysics. 


\section{Selective Adsorption and Separation of CNTs}

Zheng et al. described the selective adsorption of DNA molecules that was dependent on the type of DNA base, and they indicated the possibility of separating SWNTs by attaching DNA molecules [1]. This idea has been followed up in numerous recent papers. When a study uses more than one ssDNA sequence for hybridization with SWNTs, selective adhesion is expected [41,44,47,50,58,59,67,71]. Albertorio et al. specifically focused on selective adhesion, and they found that the binding strengths between nucleobases and SWNTs followed the order G $>\mathrm{C}>\mathrm{A}>\mathrm{T}[80]$.

Multiple studies have reported on the separation of specific SWNTs using selective adhesion of DNA molecules [50,59,61,68,80-83]. Currently, the chirality of SWNTs cannot be well controlled during synthesis. A technique for separating SWNTs is one of the major aims of CNT research [62,84-93]. For example, Vetcher et al. separated DNA/RNA-SWNT hybrids using agarose gel electrophoresis [84].

Chromatography techniques have also been used to purify or separate DNA-CNT hybrids. Bauer et al. prepared three types of hybrids: octadecylamine functionalization (SWNT-ODA) in tetrahydrofuran (THF), butyl group functionalization (SWNT-butyl) in THF, and DNA-SWNT hybrids. Then, the hybrids were separated by size-exclusion chromatography (SEC) in 2007 [85]. They also found that the molar mass of the hybrids was proportional to the rod length of the SWNTs [87]. Chun et al. used flow-field flow fractionation (flow-FFF) to separate DNA-SWNT hybrids [88]. Asada et al. reported the separation of DNA-SWNTs by length and the separation of DNA-DWNTs using size-exclusion high-performance liquid chromatography (HPLC) [90]. Much progress using chromatographic methods for separation was demonstrated by $\mathrm{Tu}$ et al. in 2009 [91] where they examined many combinations of ssDNA molecules with specific sequences and SWNTs with various chiralities. They found that 12 major single-chirality semiconducting SWNTs could be separated by ion-exchange chromatography, and the results of the separation are clearly indicated in the absorption spectra (Figure 2).

Although most separation studies focus on hybrids of SWNTs, Kim et al. reported DWNT hybrids as a function of nanotube diameter, suggesting that stronger van der Waals forces between large-diameter tubes were an important factor [89]. Shakhmaeva et al. proposed a unique method of removing DNA molecules from CNT surfaces. Using divalent metal ions, the state of plasmid DNA changed from supercoiled to relaxed form and regulated the adhesion of DNA molecules onto the CNTs [92]. Tardani et al. presented the effects of polymers and ionic strength on the phase separation of DNA-SWNT suspensions [93].

Separation and purification studies have been an area of intense focus because they are absolutely vital for progress in CNT nanotechnology. If separation techniques can be applied to DNA nanotechnology, this may open a new field of study. 


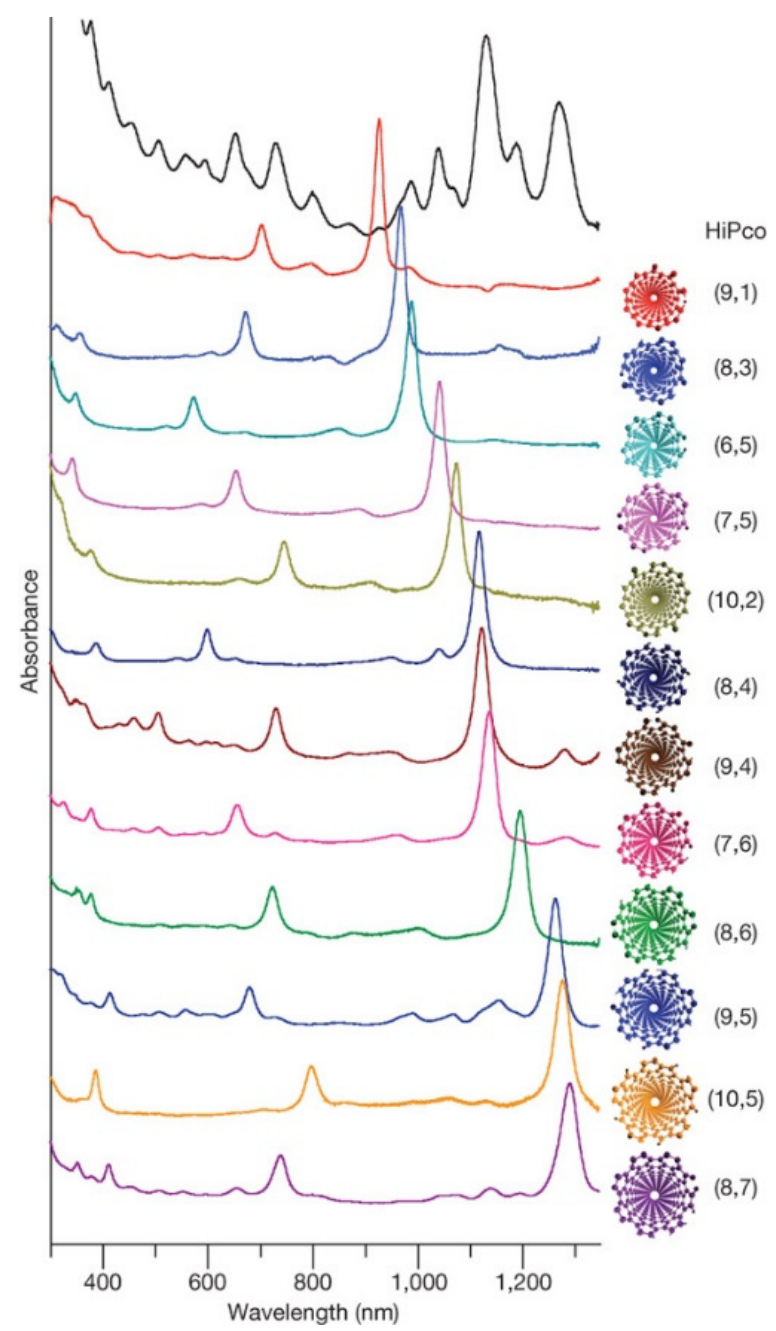

Figure 2. Optical absorption spectra of separated SWNTs by selective adsorption of ssDNA, reported by Tu et al. (Reprinted from reference [91] with permission).

\section{Characterization of DNA-CNT Hybrids}

The structural, physical, and chemical properties of DNA-CNT hybrids have been characterized by various methods, including UV-Vis spectroscopy (UV-Vis), near infrared (NIR) spectroscopy, Raman spectroscopy, photoluminescence (PL), transmission electron microscopy (TEM), scanning electron microscopy (SEM), scanning probe microscopy (SPM), and agarose gel electrophoresis. Because SWNTs have unique optical properties, spectroscopic studies are a prevalent approach to study hybrids $[41,42,46,48,54,71,81,94-115]$.

Raman spectroscopy has been utilized since the establishment of hybridization research. Glamazda et al. described spectroscopic differences between DNA-SWNTs and SDS-SWNTs using Raman spectroscopy in 2006 [94]. Shoda et al. reported a decrease in the G-band in Raman spectra with DNA adsorption, only in the case of metallic tubes [106]. Simpson et al. performed Raman spectroscopy of length-separated fractions of ssDNA-SWNT hybrids to evaluate the role of defects in the fluorescence quantum yield of SWNTs [107]. Chen et al. attached silver nanoparticles onto DNA-SWNT hybrids to measure surface-enhanced Raman scattering (SERS). From the SERS measurements, they suggested that DNA-SWNT hybrids could be useful as nanoprobes for marking cells [108]. 
Jeng et al. suggested that an ssDNA-SWNT hybrid concentration of $6 \mathrm{nM}$ could be detected using NIR band-gap fluorescence [95]. Asada et al. performed various types of spectroscopies involving NIR to assess charge transport on DNA-SWNT hybrids [98]. Karachevtsev et al. achieved glucose sensing by measuring the NIR spectra of DNA-SWNT hybrids using enzyme reactions [99]. Tu et al. reported a redox reaction of ssDNA-SWNT hybrids, suggesting that the NIR signals were tunable by the type and $\mathrm{pH}$ of the buffer solutions used [100]. Xu et al. described the potential of DNA-SWNT hybrids in immunoassays and glucose sensing as DNA-SWNT hybrids were optically sensitive to $\mathrm{H}_{2} \mathrm{O}_{2}$ and glucose in the NIR measurements [101]. Cao et al. suggested that red shifts in NIR absorption spectra were significant in hybrids with semiconducting SWNTs, but not in those with metallic SWNTs [102]. Noguchi et al. found that the optical properties of the dsDNA-SWNT hybrids could be modulated by changing the $\mathrm{pH}$ of the solution [81]. Ozturk et al. performed Raman spectroscopy on DNA-SWNT hybrids that were prepared with poly $(A)$, poly $(T)$, poly $(G)$, and poly $(C)$ at different lengths. Their results indicated that although the kinetics of DNA adsorption was affected by DNA length, the electronic properties of the DNA-SWNT hybrids were dependent on the species of DNA bases used [114]. Hobbie et al. examined the properties of G30 NIR [42], and Gladchenko et al. combined Raman spectroscopy with NIR to evaluate sonicated dsDNA that contained ssDNA regions [48]. Ishibashi et al. also used UV-Vis-NIR and Raman spectroscopy for comparative studies of poly(A), $\operatorname{poly}(\mathrm{C})$, and $\operatorname{poly}(\mathrm{G})[50]$.

Lacerda et al. demonstrated that nanotube aggregation and bundling led to decreased PL [97]. Cathcart et al. examined the aging effects of the DNA-SWNT hybrids on PL, observing that between 20 and 50 days after sample preparation, the PL intensity of the hybrids increased [103]. They also reported an increase in the PL intensity of SWNTs with decreasing concentrations of SWNTs, as mentioned in the previous section [54]. Schmucker discussed the PL spectra of hybrid DNA molecules modified with pyrene and SWNTs [78]. Ignatova et al. suggested fluorescence resonance energy transfer (FRET) could occur between two rare earth ions and the ionized phosphate groups of DNA [110]. Shao et al. combined a classical ruthenium (II) complex with guanine to yield tunable PL materials [111]. Hughes et al. used PL to compare 15-m of A, G, C, and T [68]. Figure 3 shows the changes in PL spectra due to solvent $\mathrm{pH}$ that were reported by Kim et al. [89]. Such phenomena are expected to apply to optical switches.

Other types of spectroscopic measurements were used by numerous investigators. Park et al. studied the kinetics of ssDNA adsorption onto SWNT surfaces using surface plasmon resonance imaging (SPRi) and demonstrated the effects of length and buffer using SPRi [109]. Badaire et al. used dynamic light scattering to estimate the length and diameter of the hybrids [40]. Tardani et al. used circular dichroism and rheology to study dsDNA-SWNT hybrids, as cited in the previous section [79]. He et al. systematically carried out various characterization methods, such as SEM, TEM, UV-Vis spectroscopy, Raman spectroscopy, and thermogravimetric analysis (TGA), to study positively and negatively charged hybrids [41].

Microscopic techniques are also powerful tools to directly characterize DNA-CNT hybrids [56,83,98,99,113,116-126]. Although TEM and SEM are major techniques, they are too broad to be adequately summarized in this section. A specific review article for using electron microscopy for studying DNA-CNT hybrids will be compiled. Here, several studies that used SPM and other specific microscopies as their main characterization methods are introduced. 


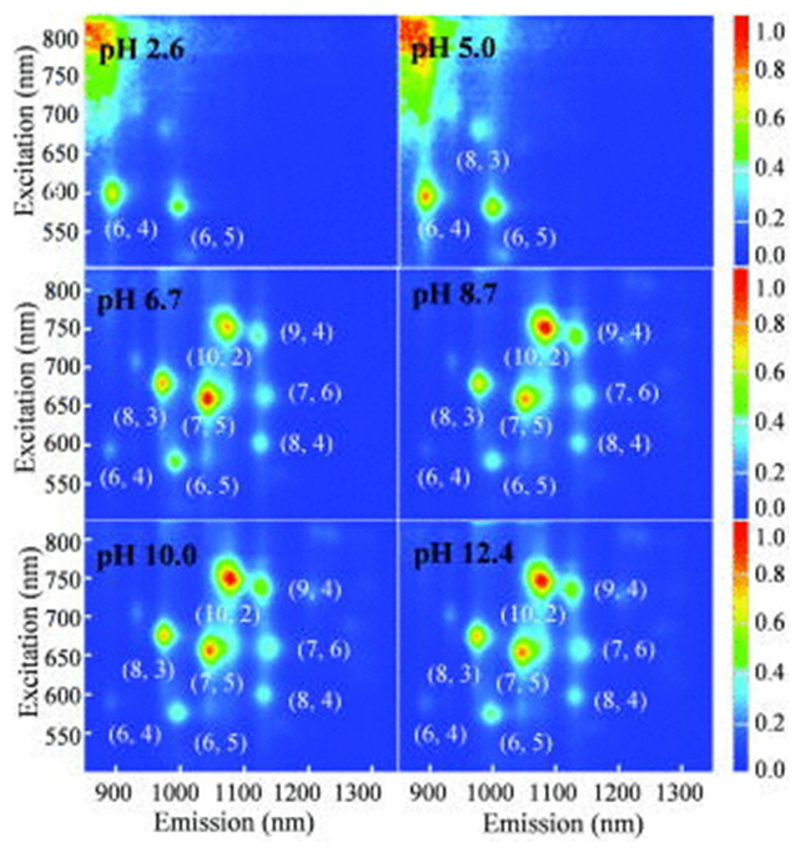

Figure 3. Differences in photoluminescence (PL) maps due to the $\mathrm{pH}$ values of solvents indicated by Kim et al. (Reprinted from reference [89] with permission).

Takahashi et al. published an article that specifically focused on atomic force microscopy (AFM) titled "AFM Imaging of Wrapped Multiwall Carbon Nanotube in DNA" in 2006. They examined dsDNA-MWNT hybrids using AFM on highly oriented pyrolytic graphite (HOPG) surfaces, and concluded that the diameters of the MWNTs strongly affected the adsorption of DNA [116]. Campbell et al. observed a regular pattern on the surface of CNT-DNA hybrids by AFM. Furthermore, they attached core/shell CdSe/ZnS quantum dots to the DNA-SWNTs using thiol-modified DNA molecules, and the attachment of the quantum dots was also confirmed by AFM [117]. Toita et al. prepared two types of SWNTs that were synthesized using high-pressure carbon monoxide (HiPco) and arc discharge (Arc) methods. Based on AFM measurements, they suggested that the adsorption mechanism of DNA molecules was affected by the diameter of SWNTs [118]. Hayashida et al. hybridized ssDNA or dsDNA using HiPco or chemical vapor deposition (CVD) methods and compared the thickness of the DNA-SWNT hybrids using cross-sections of AFM images. They found that the manner of adsorption was significantly different among the four combinations of hybridization [122]. Nii et al. studied the adsorption and desorption of dsDNA onto/away from SWNTs that were functionalized with polyethylene glycol (PEG), which was confirmed by cross-sectional analysis of AFM images and agarose gel electrophoresis [113]. Using a similar experimental approach, Nii et al. also reported the selective binding of ssDNA-binding (SSB) proteins to ssDNA-SWNTs, but not to dsDNA-SWNT hybrids [123].

Force spectroscopy is an advanced mode of AFM. Using force spectroscopy, Iliafar et al. found that the binding strength of ssDNA to curved SWNTs is much greater than that to flat graphite [83]. Figure 4 shows an example of their force spectroscopic data. Moreover, they estimated the free energy of DNA binding to SWNTs for every nucleic base. Qiu et al. carried out force spectroscopy to measure the electrostatic forces between $\mathrm{GT}_{20}$ and SWNTs [77]. 


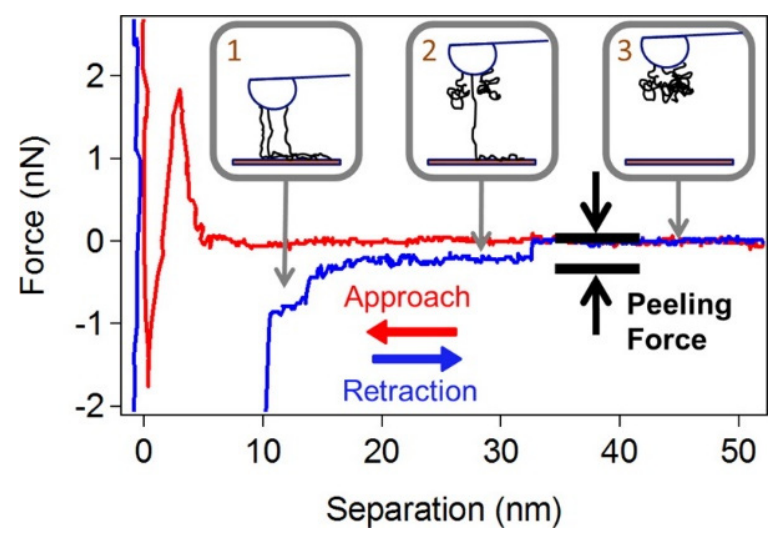

Figure 4. A typical force curve during the peeling of a $\mathrm{T}_{100}$ ssDNA molecule away from a SWNT surface, demonstrated by Iliafar et al. (Reprinted from reference [83] with permission).

Several unique approaches related to microscopic methods have been demonstrated. Xu et al. investigated the motion of SWNTs in solution using optical trapping techniques and scanning photocurrent microscopy [119]. For measurement, microbeads were attached to SWNTs via DNA molecules. The study demonstrated that the surface potential against Au substrate varied depending on the type of SWNTs. Arnett et al. reacted ssDNA ligase with DNA-CNT hybrids that were prepared with pyrimidine-functionalized CNTs and observed the formation of a 3D lattice-like CNT structure using wet-cell TEM [120]. Hayashida et al. performed Kelvin force microscopy to measure the surface potential of ssDNA-SWNT hybrids and other related samples [121].

Electrophoresis methods are popular in biology and have been applied to characterize DNA-CNT hybrids. For example, Vetcher et al. employed agarose gel electrophoresis to characterize separated DNA/RNA-SWNT hybrids [84]. Nii et al. combined staining of DNA molecules using ethidium bromide (EtBr), of proteins with Coomassie Brilliant Blue (CBB), and direct observation without staining for SWNTs to characterize DNA-SWNT hybrids after SSB reaction [123]. Figure 5 shows the results of the electrophoresis presented by Nii et al., where significant differences between ssDNA and dsDNA were observed in the electrophoresis patterns.

Fluorescent spectroscopy and fluorescent microscopy revealed a peculiar quenching phenomenon [127-137]. Rao et al. confirmed the binding of poly(rU) molecules using single-molecule fluorescence microscopy and Raman spectroscopy [127]. Yang et al. described carbon nanotube-quenched fluorescent oligonucleotides and hairpin-structured fluorescent oligonucleotides [128]. Zhang et al. detected mercury ions $\left(\mathrm{Hg}^{2+}\right)$ in an aqueous solution using fluorescence quenching [129]. Zhao et al. prepared a reusable fluorescent sensor using DNA-SWNT hybrids for highly sensitive and selective detection of $\mathrm{Ag}^{+}$and cysteine (Cys) in aqueous solutions [130]. D'Souza et al. used ssDNA hybrids to measure electron transfer in self-assemblies of ion-paired porphyrins employing $(6,5)$ and $(7,6)$ semiconductive SWNTs [131]. Martinez et al. found that streptavidin was an effective linker between SWNTs and oligonucleotides, and therefore, streptavidin efficiently prevented the non-specific adsorption of high-affinity molecules, such as DNA, onto CNTs [134]. Judkins et al. performed EPI-fluorescence microscopy (EFM) on DNA-SWNT hybrids to estimate their diffusion constants [137]. In this study, SWNTs were non-covalently coated with 1-pyrenebutanoic succinimidyl ester (PSE) as a fluorophore, and then DNA molecules were covalently attached to the PSE. This study suggested these tools could be used in the development of drug delivery systems. 


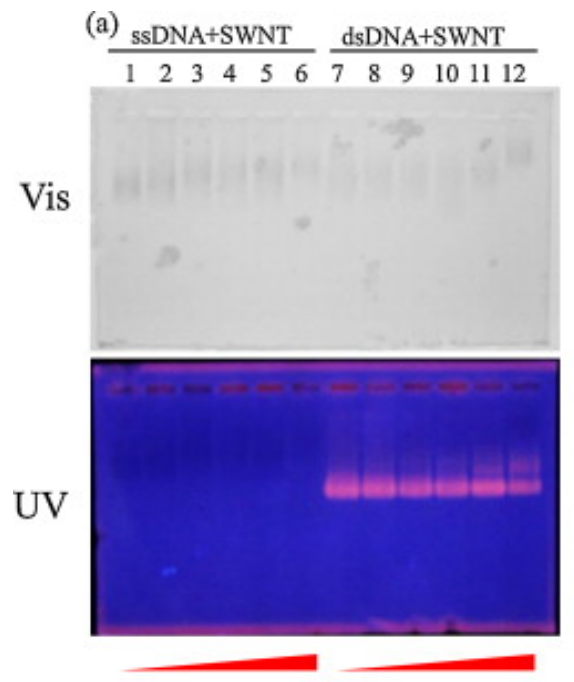

E. coli $\mathrm{SSB}$ concentration

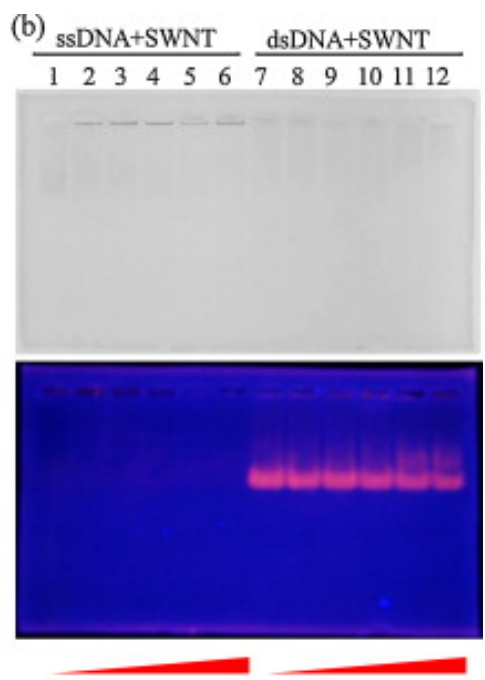

E. coli SSB concentration

Figure 5. An example of agarose gel electrophoresis of DNA-SWNT hybrids with and without ssDNA-binding (SSB) proteins as performed by Nii et al. (Reprinted from reference [123] with permission).

There has been much work done in characterizing the physical and chemical properties of DNA-CNT hybrids. This is especially true for various nanomaterials where specific optical properties of CNTs seem to depend on CNT chirality and DNA sequence. A future application of this work might include development of optical sensors and switches. However, it is important to note that when a fluorescent dye is linked to DNA, quenching can occur on the CNT surface. If there are excess unbound DNA molecules nearby, this quenching can be difficult to observe.

These studies also indicate the importance of single-molecule measurements. In order to determine specific physical properties of CNTs, further progress using single-molecule techniques is needed. For example, if single-molecule electrophoresis were possible for DNA-CNT hybrids, this would be a powerful method to characterize DNA-CNT hybrids.

\section{Functionalization of CNTs for DNA Attachment}

The use of functionalized CNTs for DNA attachment is a prevalent approach in hybridization research [138-150]. In most cases of this approach, DNA molecules are covalently attached onto the functionalized CNTs. CNT structures should be chemically modified, and therefore, the physical and chemical properties of the CNTs should also be different in comparison with those of bare CNTs.

Hazani et al. attached ssDNA molecules onto SWNT surfaces using carbodiimide-assisted amidation in 2003 [138]. They characterized the samples using UV-Vis spectroscopy and confocal fluorescence microscopy and revealed hybridization of the ssDNA-SWNT hybrids with complementary ssDNA. Stevens et al. prepared fluorinated SWNTs (fluoronanotubes) to covalently attach various molecules such as DNA in 2003 [139]. Singh et al. synthesized conjugates of peptide nucleic acid (PNA, an artificial analogue of DNA) and SWNTs [141]. Wang et al. functionalized SWNTs with carboxylic groups and DNA molecules with amino groups and hybridized them using amide linkages [142]. Yang et al. covalently attached DNA molecules onto oxidized SWNT surfaces in organic and aqueous solutions. The attachment of the DNA molecules was confirmed by TEM using complementary DNA 
molecules that were functionalized using gold nanoparticles with ssDNA-SWNT conjugates [144]. Moghaddam et al. formed photo-adducts on graphitic surfaces using $N$-5-azido-nitrobenzoyloxy succinimide (ANB-NOS) and covalently attached DNA molecules that were terminated with amine groups [145]. Alidori et al. prepared ammonium-functionalized CNTs for DNA attachment [146]. Dolash et al. proposed a model in which covalent bonding was formed between DNA and CNTs using sonication [147]. Singh et al. developed the covalent double functionalization method using oxidized SWNTs with a combination of purine-pyrimidine and purine-purine nucleobases [148]. Canete-Rosales et al. fabricated hybrids of single-stranded deoxyoligonucleotide oligomers (DNO) and CNTs using both covalent and non-covalent attachment [149]. Kaufmann et al. functionalized MWNTs with hydroxyl groups [150], subsequently attaching a carrier strand oligodeoxynucleotide (CS-ODN) to the functionalized MWNTs and hybridizing a therapeutic antisense oligodeoxynucleotide (AS-ODN) with the conjugates. Finally, Yuan et al. reviewed the various functionalization methods [143].

Although not a chemical functionalization method of CNTs, the insertion of DNA molecules into CNTs is a unique idea [36,69,124,126,151-157]. For example, Gao et al. predicted that a DNA could possibly be spontaneously inserted into CNTs using molecular dynamics (MD) simulations [151]. Okada et al. demonstrated insertion of ssDNA molecules into SWNTs using ion irradiation in electrolyte plasma [152,153]. Lulevich et al. pulled a DNA molecule out of a SWNT using an AFM probe. Since the measured force was nearly constant, they suggested that the removal of the DNA molecule was frictionless [126].

Many new small companies that commercialize the functionalization of CNT products have been established. These companies are quite valuable for physicists and biologists who do not synthesize their own CNTs. Currently, since each company proposes their own protocols, qualities of some functionalized CNTs are dependent on manufacturers even though similar structural formulas are written in their catalogs. Further accumulation of the use of functionalized CNTs is necessary for the DNA nanotechnology field.

\section{Theoretical Studies of Nucleic Acid Adsorption to CNTs}

The combination of theoretical and experimental approaches is a trend in fundamental hybridization research of nucleic acids and CNTs [155,158-174]. Enyashin et al. employed a quantum mechanical density-functional tight-binding method (DFTB) to assess the adsorption of DNA molecules onto CNT surfaces [158]. Frischknecht et al. performed atomistic MD simulations to measure the binding energy of six different nucleotide monophosphates (NMPs) under two distinctive environmental conditions. They established that the binding energy between the NMPs and $(6,0)$ SWNTs is a few kilocalories/mole [159]. Roxbury et al. studied sequence-specific self-stitching motifs of short ssDNA using replica exchange molecular dynamics (REMD) [164]. Umadevi et al. demonstrated that the binding energy between CNTs and DNA/RNA nucleobases could be controlled by the curvature of the CNTs using quantum chemical calculations [165]. Xiao et al. studied sequence- and base-dependent interactions using all atom MD simulations and thermodynamic analyses based on their fundamental interests [166]. Akdim et al. examined the selectivity of DNA-CNT hybridization using density functional theory calculations [167]. While ssDNA has mainly been studied from the theoretical aspect, Alegret et al. investigated dsDNA-SWNT hybrids using MD simulations [168]. Their results indicated 
that the disruption of short dsDNA helices was accelerated in the presence of SWNTs. Roxbury et al. reported that DNA formed ordered structures on SWNT surfaces, and the structures are strongly dependent on the sequence of the DNA and the types of SWNTs [169]. Figure 6 depicts their theoretical models of ssDNA-SWNT hybridization with distinct sequences and chiralities. Santosh et al. suggested that dsDNA undergoes much less unzipping and wrapping on SWNTs within $70 \mathrm{~ns}$ using MD simulations [170]. Wu et al. indicated that bundled CNTs can be dispersed by applying torsional energy based on MD simulations [174]. Iliafar verified their experimental data using REMD [112]. Makarucha et al. presented a review article to summarize theoretical research in this field in 2011 [163].

In the past ten years, theoretical modeling has proven useful for examining various conditions of DNA-CNT hybridization. Theoretical models of dsDNA-CNT hybrids, not only ssDNA-CNT hybrids, have also recently been proposed. At this stage, systematic combination of theoretical and experimental studies might be required.

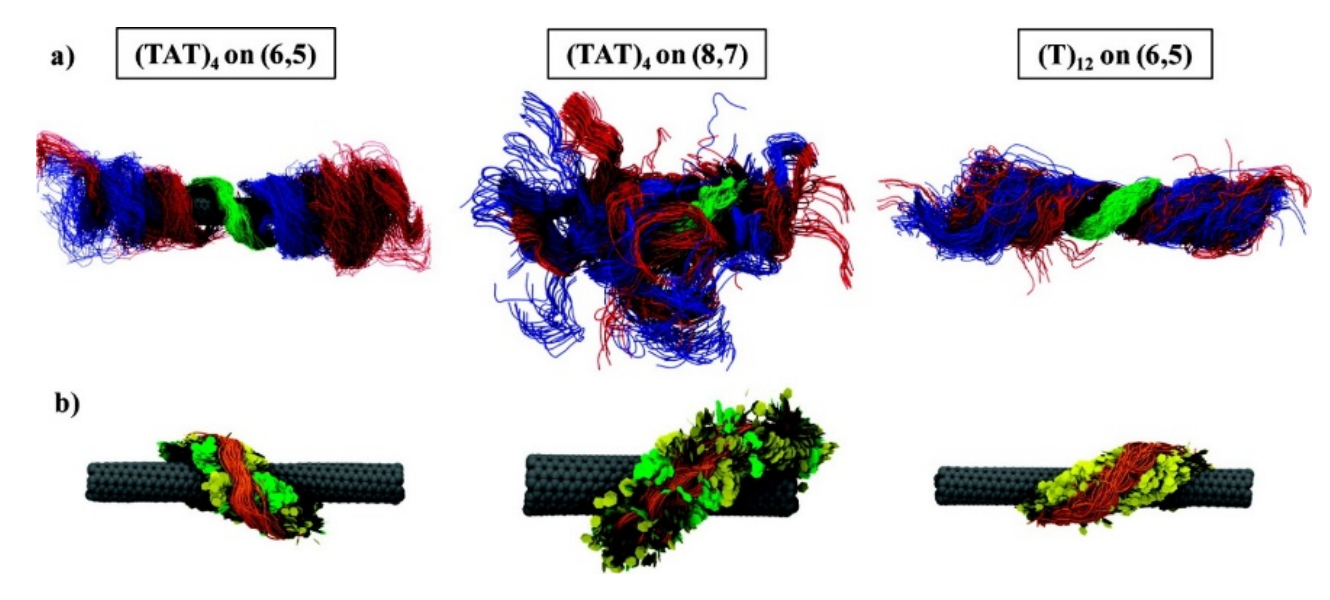

Figure 6. Recent theoretical models of several combinations of ssDNA and SWNTs, proposed by Roxbury et al. (Reprinted from reference [169] with permission).

\section{Biological Applications}

Although much work has focused on the fundamental aspects of DNA-CNT hybridization, many recent reports have presented ideas for and demonstrations of biological applications $[40,43,50,55,56,63,64,67,74-76,82,99,101,108,112,117,130,133,175-200]$. The following describes several examples.

Biosensors comprise a widespread field in the application of DNA-CNT hybrids. Zhang et al. reported the selective detection of single nitric oxide (NO) molecules. In this study, (AT) 15 ssDNA was adsorbed onto an array of near-infrared fluorescent semiconducting SWNTs, which resulted in AT15-SWNT hybrids [133]. Zhang et al. achieved label-free detection of sequence-specific DNA using MWNTs, noting that the mismatch of a single base could be detected using light scattering signals [176]. Aravind et al. demonstrated the detection of dopamine using ssDNA-MWNTs [180]. Cao et al. developed a highly sensitive immunosensor for detecting human chorionic gonadotrophin (HCG) using dsDNA-MWNT hybrids and methylene blue (MB) on a glass carbon electrode [182]. Shi et al. fabricated highly sensitive glucose and ATP microbiosensors using ssDNA-SWNT hybrids [185]. Thuy et al. detected Escherichia coli O157:H7 using DNA-MWNT hybrids [189]. 
Su et al. fabricated gas sensors for $\mathrm{H}_{2}, \mathrm{H}_{2} \mathrm{~S}, \mathrm{NH}_{3}$, and $\mathrm{NO}_{2}$ using metal-DNA-SWNT hybrids on microfabricated electrodes [195].

Kawaguchi et al. used dsDNA-SWNT hybrids as heat delivery vehicles for the thermal ablation of tumors. Anti-human IgG was attached to the hybrids for specific binding with the targeted protein molecules [187]. The attachment of quantum dots to DNA-CNT hybrids was reported by several authors [117,190]. Gong et al. found that molecular structural switching of $\mathrm{T}_{15}$ adsorbed onto SWNTs was induced when the sample was exposed to $\mathrm{Hg}^{2+}$ [192]. Williams et al. described an inhibitory concentration of DNA-SWNTs in PCR reactions [200]. Mangalum et al. fabricated unique structures by combining ssDNA-SWNT hybrids and DNA origami techniques, as shown in Figure 7 [193].

Finally, the interaction between nucleic acids and graphene has becoming a major area of interest [201-219], and the safety of CNTs is an important area of research [220-245]. Further review articles that focus on these topics will be compiled.

The number of biological applications has increased drastically over the past several years. This suggests that biophysicists and biochemists can use DNA-CNT hybrids even though they do not specialize in CNTs. Although fundamental analysis of DNA-CNT hybridization is an important area of research, it appears that biological applications can be developed using our present understanding of DNA-CNT hybrids.

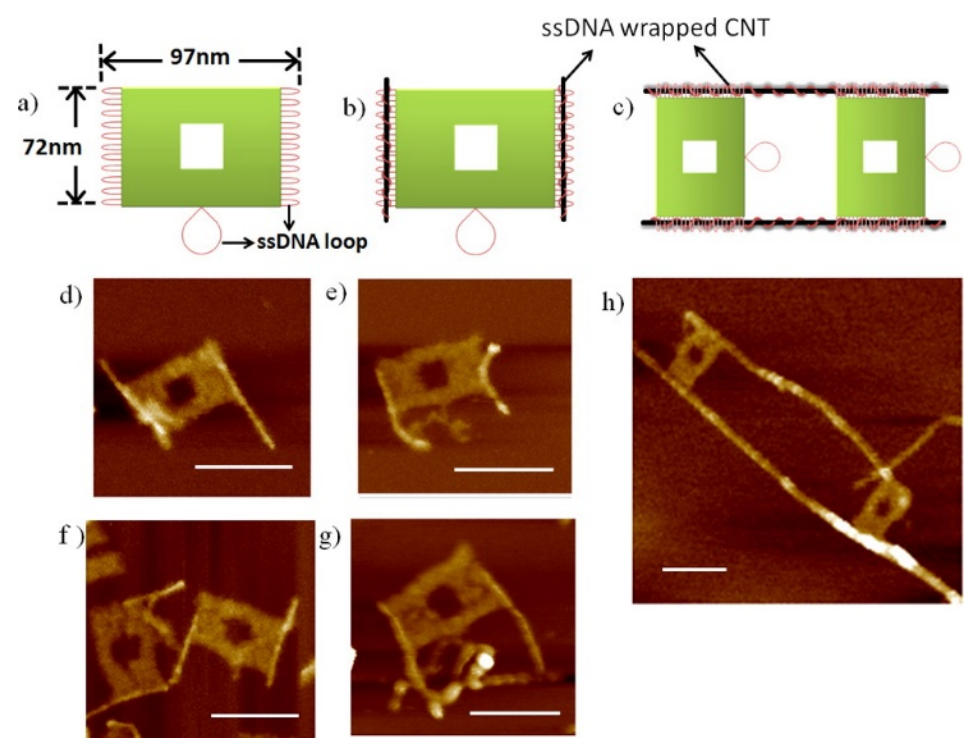

Figure 7. Schematic representations and AFM images of structures fabricated with ssDNA-SWNT hybrids using the DNA origami technique, generated by Mangalum et al. (Reprinted from reference [193] with permission).

\section{Conclusions}

In this review, biological applications of CNT hybrids with nucleic acids are discussed and categorized by several key factors. This survey suggests that fundamental research of the hybridization phenomenon of nucleic acids and CNTs has continued intensively from both theoretical and experimental viewpoints. Progress in practical applications, such as fabrication of nanosensors, has recently accelerated. Some topics cannot be covered in this article, and thus, more specific review articles will be written in the future. 


\section{Acknowledgments}

This work was supported by Grant-in-Aid for Scientific Research (26400436) of the Japan Society for the Promotion of Science (JSPS).

\section{Conflicts of Interest}

The author declares no conflict of interest.

\section{References}

1. Zheng, M.; Jagota, A.; Semke, E.D.; Diner, B.A.; McLean, R.S.; Lustig, S.R.; Richardson, R.E.; Tassi, N.G. DNA-assisted dispersion and separation of carbon nanotubes. Nat. Mater. 2003, 2 , $338-342$.

2. Nakashima, N.; Okuzono, S.; Murakami, H.; Nakai, T.; Yoshikawa, K. DNA dissolves single-walled carbon nanotubes in water. Chem. Lett. 2003, 32, 456-457.

3. O’Connell, M.J.; Boul, P.; Ericson, L.M.; Huffman, C.; Wang, Y.H.; Haroz, E.; Kuper, C.; Tour, J.; Ausman, K.D.; Smalley, R.E. Reversible water-solubilization of single-walled carbon nanotubes by polymer wrapping. Chem. Phys. Lett. 2001, 342, 265-271.

4. Fu, K.F.; Huang, W.J.; Lin, Y.; Zhang, D.H.; Hanks, T.W.; Rao, A.M.; Sun, Y.P. Functionalization of carbon nanotubes with bovine serum albumin in homogeneous aqueous solution. J. Nanosci. Nanotechnol. 2002, 2, 457-461.

5. Huang, W.J.; Lin, Y.; Taylor, S.; Gaillard, J.; Rao, A.M.; Sun, Y.P. Sonication-assisted functionalization and solubilization of carbon nanotubes. Nano Lett. 2002, 2, 231-234.

6. Star, A.; Stoddart, J.F. Dispersion and solubilization of single-walled carbon nanotubes with a hyperbranched polymer. Macromolecules 2002, 35, 7516-7520.

7. Dodziuk, H.; Ejchart, A.; Anczewski, W.; Ueda, H.; Krinichnaya, E.; Dolgonos, G.; Kutner, W. Water solubilization, determination of the number of different types of single-wall carbon nanotubes and their partial separation with respect to diameters by complexation with eta-cyclodextrin. Chem. Commun. 2003, 8, 986-987.

8. Jiang, L.Q.; Gao, L.; Sun, J. Production of aqueous colloidal dispersions of carbon nanotubes. J. Colloid Interface Sci. 2003, 260, 89-94.

9. Petrov, P.; Stassin, F.; Pagnoulle, C.; Jerome, R. Noncovalent functionalization of multi-walled carbon nanotubes by pyrene containing polymers. Chem. Commun. 2003, 23, 2904-2905.

10. Wang, J.; Musameh, M.; Lin, Y.H. Solubilization of carbon nanotubes by nafion toward the preparation of amperometric biosensors. J. Am. Chem. Soc. 2003, 125, 2408-2409.

11. Hasegawa, T.; Fujisawa, T.; Numata, M.; Umeda, M.; Matsumoto, T.; Kimura, T.; Okumura, S.; Sakurai, K.; Shinkai, S. Single-walled carbon nanotubes acquire a specific lectin-affinity through supramolecular wrapping with lactose-appended schizophyllan. Chem. Commun. 2004, 19, 2150-2151.

12. Zhang, M.G.; Smith, A.; Gorski, W. Carbon nanotube-chitosan system for electrochemical sensing based on dehydrogenase enzymes. Anal. Chem. 2004, 76, 5045-5050.

13. Liu, P. Modifications of carbon nanotubes with polymers. Eur. Polym. J. 2005, 41, 2693-2703. 
14. Sinani, V.A.; Gheith, M.K.; Yaroslavov, A.A.; Rakhnyanskaya, A.A.; Sun, K.; Mamedov, A.A.; Wicksted, J.P.; Kotov, N.A. Aqueous dispersions of single-wall and multiwall carbon nanotubes with designed amphiphilic polycations. J. Am. Chem. Soc. 2005, 127, 3463-3472.

15. Yan, Y.M.; Zhang, M.N.; Gong, K.P.; Su, L.; Guo, Z.X.; Mao, L.Q. Adsorption of methylene blue dye onto carbon nanotubes: A route to an electrochemically functional nanostructure and its layer-by-layer assembled nanocomposite. Chem. Mater. 2005, 17, 3457-3463.

16. Wang, D.; Chen, L.W. Temperature and ph-responsive single-walled carbon nanotube dispersions. Nano Lett. 2007, 7, 1480-1484.

17. Wise, A.J.; Smith, J.R.; Bouropoulos, N.; Yannopoulos, S.N.; van der Merwe, S.M.; Fatouros, D.G. Single-wall carbon nanotube dispersions stabilised with $N$-trimethyl-chitosan. J. Biomed. Nanotechnol. 2008, 4, 67-72.

18. Plisko, T.V.; Bildyukevich, A.V. Debundling of multiwalled carbon nanotubes in N, N-dimethylacetamide by polymers. Colloid Polym. Sci. 2014, 292, 2571-2580.

19. Niyogi, S.; Hamon, M.A.; Hu, H.; Zhao, B.; Bhowmik, P.; Sen, R.; Itkis, M.E.; Haddon, R.C. Chemistry of single-walled carbon nanotubes. Accounts Chem. Res. 2002, 35, 1105-1113.

20. Williams, K.A.; Veenhuizen, P.T.M.; de la Torre, B.G.; Eritja, R.; Dekker, C. NanotechnologyCarbon nanotubes with DNA recognition. Nature 2002, 420, 761-761.

21. Fu, K.F.; Sun, Y.P. Dispersion and solubilization of carbon nanotubes. J. Nanosci. Nanotechnol. 2003, 3, 351-364.

22. Martin, C.R.; Kohli, P. The emerging field of nanotube biotechnology. Nat. Rev. Drug Discov. 2003, 2, 29-37.

23. Jin, W.J.; Sun, X.F.; Wang, Y. Solubilization and functionalization of carbon nanotubes. New Carbon Mater. 2004, 19, 312-318.

24. Lin, Y.; Taylor, S.; Li, H.P.; Fernando, K.A.S.; Qu, L.W.; Wang, W.; Gu, L.R.; Zhou, B.; Sun, Y.P. Advances toward bioapplications of carbon nanotubes. J. Mater. Chem. 2004, 14, 527-541.

25. Pividori, M.I.; Alegret, S. DNA Adsorption on Carbonaceous Materials. In Immobilisation of DNA on Chips I; Wittmann, C., Ed.; Springer-Verlag Berlin: Berlin, Germany, 2005; Volume 260, pp. 1-36.

26. Nakashima, N. Solubilization of single-walled carbon nanotubes with condensed aromatic compounds. Sci. Technol. Adv. Mater. 2006, 7, 609-616.

27. Daniel, S.; Rao, T.P.; Rao, K.S.; Rani, S.U.; Naidu, G.R.K.; Lee, H.Y.; Kawai, T. A review of DNA functionalized/grafted carbon nanotubes and their characterization. Sens. Actuator B 2007, 122, $672-682$.

28. Wei, W.; Sethuraman, A.; Jin, C.; Monteiro-Riviere, N.A.; Narayan, R.J. Biological properties of carbon nanotubes. J. Nanosci. Nanotechnol. 2007, 7, 1284-1297.

29. Tu, X.M.; Zheng, M. A DNA-based approach to the carbon nanotube sorting problem. Nano Res. 2008, 1, 185-194.

30. Becerril, H.A.; Woolley, A.T. DNA-templated nanofabrication. Chem. Soc. Rev. 2009, 38, 329-337.

31. Cheung, W.; Chiu, P.L.; Parajuli, R.R.; Ma, Y.F.; Ali, S.R.; He, H.X. Fabrication of high performance conducting polymer nanocomposites for biosensors and flexible electronics: Summary of the multiple roles of DNA dispersed and functionalized single walled carbon nanotubes. J. Mater. Chem. 2009, 19, 6465-6480. 
32. Sanchez-Pomales, G.; Santiago-Rodriguez, L.; Cabrera, C.R. DNA-functionalized carbon nanotubes for biosensing applications. J. Nanosci. Nanotechnol. 2009, 9, 2175-2188.

33. Zhao, Y.L.; Stoddart, J.F. Noncovalent functionalization of single-walled carbon nanotubes. Accounts Chem. Res. 2009, 42, 1161-1171.

34. Fujigaya, T.; Tanaka, Y.; Nakashima, N. Soluble carbon nanotubes and application to electrochemistry. Electrochemistry 2010, 78, 2-15.

35. Lei, J.P.; Ju, H.X. Nanotubes in biosensing. Nanomed. Nanobiotechnol. 2010, 2, 496-509.

36. Contreras-Torres, F.F.; Martinez-Loran, E. DNA insertion in and wrapping around carbon nanotubes. Comput. Mol. Sci. 2011, 1, 902-919.

37. Zhang, W.X.; Zhang, Z.Z.; Zhang, Y.G. The application of carbon nanotubes in target drug delivery systems for cancer therapies. Nanoscale Res. Lett. 2011, 6, doi:10.1186/1556-276X-6-555.

38. Zhang, X.Q.; Xu, X.Y.; Lam, R.; Giljohann, D.; Ho, D.; Mirkin, C.A. Strategy for increasing drug solubility and efficacy through covalent attachment to polyvalent DNA-Nanoparticle conjugates. ACS Nano 2011, 5, 6962-6970.

39. Barisci, J.N.; Tahhan, M.; Wallace, G.G.; Badaire, S.; Vaugien, T.; Maugey, M.; Poulin, P. Properties of carbon nanotube fibers spun from DNA-stabilized dispersions. Adv. Funct. Mater. 2004, 14, 133-138.

40. Badaire, S.; Zakri, C.; Maugey, M.; Derre, A.; Barisci, J.N.; Wallace, G.; Poulin, P. Liquid crystals of DNA-stabilized carbon nanotubes. Adv. Mater. 2005, 17, 1673-1676.

41. He, P.G.; Bayachou, M. Layer-by-layer fabrication and characterization of DNA-wrapped single-walled carbon nanotube particles. Langmuir 2005, 21, 6086-6092.

42. Hobbie, E.K.; Bauer, B.J.; Stephens, J.; Becker, M.L.; McGuiggan, P.; Hudson, S.D.; Wang, H. Colloidal particles coated and stabilized by DNA-wrapped carbon nanotubes. Langmuir 2005, 21, 10284-10287.

43. Hu, C.G.; Zhang, Y.Y.; Bao, G.; Zhang, Y.L.; Liu, M.L.; Wang, Z.L. DNA functionalized single-walled carbon nanotubes for electrochemical detection. J. Phys. Chem. B 2005, 109, 20072-20076.

44. Yan, W.; Shen, X.C.; Zhang, Z.L.; Chen, C.; Pang, D.W. Electrochemical behavior of daunorubicin at DNA-MWCNT bioconjugates modified glassy carbon electrodes. Anal. Lett. 2005, 38, 2579-2595.

45. Chen, R.J.; Zhang, Y.G. Controlled precipitation of solubilized carbon nanotubes by delamination of DNA. J. Phys. Chem. B 2006, 110, 54-57.

46. Fagan, J.A.; Landi, B.J.; Mandelbaum, I.; Simpson, J.R.; Bajpai, V.; Bauer, B.J.; Migler, K.; Walker, A.R.H.; Raffaelle, R.; Hobbie, E.K. Comparative measures of single-wall carbon nanotube dispersion. J. Phys. Chem. B 2006, 110, 23801-23805.

47. Gigliotti, B.; Sakizzie, B.; Bethune, D.S.; Shelby, R.M.; Cha, J.N. Sequence-independent helical wrapping of singles-walled carbon nanotubes by long genomic DNA. Nano Lett. 2006, 6, 159-164.

48. Gladchenko, G.O.; Karachevtsev, M.V.; Leontiev, V.S.; Valeev, V.A.; Glamazda, A.Y.; Plokhotnichenko, A.M.; Stepanian, S.G. Interaction of fragmented double-stranded DNA with carbon nanotubes in aqueous solution. Mol. Phys. 2006, 104, 3193-3201. 
49. Ikeda, A.; Hamano, T.; Hayashi, K.; Kikuchi, J. Water-solubilization of nucleotides-coated single-walled carbon nanotubes using a high-speed vibration milling technique. Org. Lett. 2006, 8 , 1153-1156.

50. Ishibashi, A.; Yamaguchi, Y.; Murakami, H.; Nakashima, N. Layer-by-layer assembly of RNA/single-walled carbon nanotube nanocomposites. Chem. Phys. Lett. 2006, 419, 574-577.

51. Onoa, B.; Zheng, M.; Dresselhaus, M.S.; Diner, B.A. Carbon nanotubes and nucleic acids: Tools and targets. Phys. Status Solidi A 2006, 203, 1124-1131.

52. Zhao, W.; Gao, Y.; Brook, M.A.; Li, Y.F. Wrapping single-walled carbon nanotubes with long single-stranded DNA molecules produced by rolling circle amplification. Chem. Commun. 2006, 3582-3584.

53. Bertoncini, P.; Gresil, M.; Lardoux, J.; Riou, I.; Chauvet, O. Morphology of DNA/single walled nanotubes complexes. Dig. J. Nanomater. Biostruct. 2007, 2, 293-297.

54. Cathcart, H.; Quinn, S.; Nicolosi, V.; Kelly, J.M.; Blau, W.J.; Coleman, J.N. Spontaneous debundling of single-walled carbon nanotubes in DNA-based dispersions. J. Phys. Chem. C 2007, 111, 66-74.

55. Han, X.G.; Li, Y.L.; Deng, Z.X. DNA-wrapped single-walled carbon nanotubes as rigid templates for assembling linear gold nanoparticle arrays. Adv. Mater. 2007, 19, 1518-1522.

56. Hopkins, A.R.; Kruk, N.A.; Lipeles, R.A. Macroscopic alignment of single-walled carbon nanotubes (SWNTs). Surf. Coat. Technol. 2007, 202, 1282-1286.

57. Jeng, E.S.; Barone, P.W.; Nelson, J.D.; Strano, M.S. Hybridization kinetics and thermodynamics of DNA adsorbed to individually dispersed single-walled carbon nanotubes. Small 2007, 3, 1602-1609.

58. Jin, H.; Jeng, E.S.; Heller, D.A.; Jena, P.V.; Kirmse, R.; Langowski, J.; Strano, M.S. Divalent ion and thermally induced DNA conformational polymorphism on single-walled carbon nanotubes. Macromolecules 2007, 40, 6731-6739.

59. Vogel, S.R.; Kappes, M.M.; Hennrich, F.; Richert, C. An unexpected new optimum in the structure space of DNA solubilizing single-walled carbon nanotubes. Chemistry 2007, 13, 1815-1820.

60. Vogel, S.R.; Muller, K.; Plutowski, U.; Kappes, M.M.; Richert, C. DNA-carbon nanotube interactions and nanostructuring based on DNA. Phys. Status Solidi B 2007, 244, 4026-4029.

61. Haggenmueller, R.; Rahatekar, S.S.; Fagan, J.A.; Chun, J.H.; Becker, M.L.; Naik, R.R.; Krauss, T.; Carlson, L.; Kadla, J.F.; Trulove, P.C.; et al. Comparison of the quality of aqueous dispersions of single wall carbon nanotubes using surfactants and biomolecules. Langmuir 2008, $24,5070-5078$.

62. Noguchi, Y.; Fujigaya, T.; Niidome, Y.; Nakashima, N. Single-walled carbon nanotubes/DNA hybrids in water are highly stable. Chem. Phys. Lett. 2008, 455, 249-251.

63. Cooper, L.; Amano, H.; Hiraide, M.; Houkyou, S.; Jang, I.Y.; Kim, Y.J.; Muramatsu, H.; Kim, J.H.; Hayashi, T.; Kim, Y.A.; et al. Freestanding, bendable thin film for supercapacitors using DNA-dispersed double walled carbon nanotubes. Appl. Phys. Lett. 2009, doi:10.1063/1.3271768.

64. Ghosh, S.; Dutta, S.; Gomes, E.; Carroll, D.; D’Agostino, R.; Olson, J.; Guthold, M.; Gmeiner, W.H. Increased heating efficiency and selective thermal ablation of malignant tissue with DNA-encased multiwalled carbon nanotubes. ACS Nano 2009, 3, 2667-2673. 
65. Jovanovic, S.P.; Markovic, Z.M.; Kleut, D.N.; Romcevic, N.Z.; Trajkovic, V.S.; Dramicanin, M.D.; Markovic, B.M.T. A novel method for the functionalization of gamma-irradiated single wall carbon nanotubes with DNA. Nanotechnology 2009, 20, doi:10.1088/0957-4484/20/44/445602.

66. Pease, L.F.; Tsai, D.H.; Fagan, J.A.; Bauer, B.J.; Zangmeister, R.A.; Tarlov, M.J.; Zachariah, M.R. Length distribution of single-walled carbon nanotubes in aqueous suspension measured by electrospray differential mobility analysis. Small 2009, 5, 2894-2901.

67. Asada, Y.; Miyata, Y.; Ohno, Y.; Kitaura, R.; Sugai, T.; Mizutani, T.; Shinohara, H. High-performance thin-film transistors with DNA-assisted solution processing of isolated single-walled carbon nanotubes. Adv. Mater. 2010, 22, 2698-2701.

68. Hughes, J.M.; Cathcart, H.; Coleman, J.N. Dispersion and exfoliation of nanotubes with synthetic oligonucleotides: Variation of dispersion efficiency and oligo-nanotube interaction with base type. J. Phys. Chem. C 2010, 114, 11741-11747.

69. Li, Z.H.; Yang, W. Capture and manipulation of hybrid DNAs by carbon nanotube bundles. Nanotechnology 2010, 21, doi:10.1088/0957-4484/21/19/195301.

70. Wang, R.R.; Sun, J.; Gao, L.A.; Zhang, J. Dispersion of single-walled carbon nanotubes by DNA for preparing transparent conductive films. J. Mater. Chem. 2010, 20, 6903-6909.

71. Yamamoto, Y.; Fujigaya, T.; Niidome, Y.; Nakashima, N. Fundamental properties of oligo double-stranded DNA/single-walled carbon nanotube nanobiohybrids. Nanoscale 2010, 2 , 1767-1772.

72. Ao, G.Y.; Nepal, D.; Aono, M.; Davis, V.A. Cholesteric and nematic liquid crystalline phase behavior of double-stranded DNA stabilized single-walled carbon nanotube dispersions. ACS Nano 2011, 5 , 1450-1458.

73. Sanz, V.; Borowiak, E.; Lukanov, P.; Galibert, A.M.; Flahaut, E.; Coley, H.M.; Silva, S.R.P.; McFadden, J. Optimising DNA binding to carbon nanotubes by non-covalent methods. Carbon 2011, 49, 1775-1781.

74. Chhikara, B.S.; Misra, S.K.; Bhattacharya, S. Cnt loading into cationic cholesterol suspensions show improved DNA binding and serum stability and ability to internalize into cancer cells. Nanotechnology 2012, 23, doi:10.1088/0957-4484/23/6/065101.

75. Wang, Y.W.; Liu, H.; Wang, F.; Gao, Y.M. Electrochemical oxidation behavior of methotrexate at DNA/SWCNT/nafion composite film-modified glassy carbon electrode. J. Solid State Electrochem. 2012, 16, 3227-3235.

76. Primo, E.N.; Canete-Rosales, P.; Bollo, S.; Rubianes, M.D.; Rivas, G.A. Dispersion of bamboo type multi-wall carbon nanotubes in calf-thymus double stranded DNA. Colloid Surf. B 2013, 108, 329-336.

77. Qiu, X.Y.; Khripin, C.Y.; Ke, F.Y.; Howell, S.C.; Zheng, M. Electrostatically driven interactions between hybrid DNA-carbon nanotubes. Phys. Rev. Lett. 2013, 111, doi:10.1103/PhysRevLett.111.048301.

78. Schmucker, W.; Klumpp, S.; Hennrich, F.; Kappes, M.; Wagenknecht, H.A. A simple pyrene "click"-type modification of DNA affects solubilisation and photoluminescence of single-walled carbon nanotubes. RSC Adv. 2013, 3, 6331-6333. 
79. Tardani, F.; Strobbia, P.; Scipioni, A.; La Mesa, C. Encapsulating carbon nanotubes in aqueous ds-DNA anisotropic phases: Shear orientation and rheological properties. $R S C A d v$. 2013, 3, 25917-25923.

80. Albertorio, F.; Hughes, M.E.; Golovchenko, J.A.; Branton, D. Base dependent DNA-carbon nanotube interactions: Activation enthalpies and assembly-disassembly control. Nanotechnology 2009, 20, doi:10.1088/0957-4484/20/39/395101.

81. Noguchi, Y.; Fujigaya, T.; Niidome, Y.; Nakashima, N. Regulation of the near-IR spectral properties of individually dissolved single-walled carbon nanotubes in aqueous solutions of dsDNA. Chemistry 2008, 14, 5966-5973.

82. Ao, G.Y.; Khripin, C.Y.; Zheng, M. DNA-controlled partition of carbon nanotubes in polymer aqueous two-phase systems. J. Am. Chem. Soc. 2014, 136, 10383-10392.

83. Iliafar, S.; Mittal, J.; Vezenov, D.; Jagota, A. Interaction of single-stranded DNA with curved carbon nanotube is much stronger than with flat graphite. J. Am. Chem. Soc. 2014, 136, 12947-12957.

84. Vetcher, A.A.; Srinivasan, S.; Vetcher, I.A.; Abramov, S.M.; Kozlov, M.; Baughman, R.H.; Levene, S.D. Fractionation of SWNT/nucleic acid complexes by agarose gel electrophoresis. Nanotechnology 2006, 17, 4263-4269.

85. Bauer, B.J.; Becker, M.L.; Bajpai, V.; Fagan, J.A.; Hobbie, E.K.; Migler, K.; Guttman, C.M.; Blair, W.R. Measurement of single-wall nanotube dispersion by size exclusion chromatography. J. Phys. Chem. C 2007, 111, 17914-17918.

86. Sanchez-Pomales, G.; Santiago-Rodriguez, L.; Rivera-Velez, N.E.; Cabrera, C.R. Characterization of the DNA-assisted purification of single-walled carbon nanotubes. Phys. Status Solidi A 2007, 204, 1791-1796.

87. Bauer, B.J.; Fagan, J.A.; Hobbie, E.K.; Chun, J.; Bajpai, V. Chromatographic fractionation of SWNT/DNA dispersions with on-line multi-angle light scattering. J. Phys. Chem. C 2008, 112, 1842-1850.

88. Chun, J.; Fagan, J.A.; Hobbie, E.K.; Bauer, B.J. Size separation of single-wall carbon nanotubes by flow-field flow fractionation. Anal. Chem. 2008, 80, 2514-2523.

89. Kim, J.H.; Kataoka, M.; Kim, Y.A.; Shimamoto, D.; Muramatsu, H.; Hayashi, T.; Endo, M.; Terrones, M.; Dresselhaus, M.S. Diameter-selective separation of double-walled carbon nanotubes. Appl. Phys. Lett. 2008, 93, doi:10.1063/1.3039790.

90. Asada, Y.; Sugai, T.; Kitaura, R.; Shinohara, H. Chromatographic length separation and photoluminescence study on DNA-wrapped single-wall and double-wall carbon nanotubes. J. Nanomater. 2009, 2009, doi:10.1155/2009/257892.

91. Tu, X.M.; Manohar, S.; Jagota, A.; Zheng, M. DNA sequence motifs for structure-specific recognition and separation of carbon nanotubes. Nature 2009, 460, 250-253.

92. Shakhmaeva, I.I.; Bulatov, E.R.; Bondar, O.V.; Saifullina, D.V.; Culha, M.; Rizvanov, A.A.; Abdullin, T.I. Binding and purification of plasmid DNA using multi-layered carbon nanotubes. J. Biotechnol. 2011, 152, 102-107.

93. Tardani, F.; la Mesa, C.; Poulin, P.; Maugey, M. Phase behavior of DNA-based dispersions containing carbon nanotubes: Effects of added polymers and ionic strength on excluded volume. J. Phys. Chem. C 2012, 116, 9888-9894. 
94. Glamazda, A.Y; Dettlaff-Weglikowska, U.; Leontiev, V.S.; Mateichenko, P.V.; Karachevtsev, V.A. Raman spectroscopy and sem study of swnts in aqueous solution and films with surfactant or polymer surroundings. Fuller. Nanotub. Carbon Nanostruct. 2006, 14, 221-225.

95. Jeng, E.S.; Moll, A.E.; Roy, A.C.; Gastala, J.B.; Strano, M.S. Detection of DNA hybridization using the near-infrared band-gap fluorescence of single-walled carbon nanotubes. Nano Lett. 2006, 6, 371-375.

96. Karachevtsev, V.A.; Glamazda, A.Y.; Dettlaff-Weglikowska, U.; Leontiev, V.S.; Mateichenko, P.V.; Roth, S.; Rao, A.M. Spectroscopic and SEM studies of SWNTs: Polymer solutions and films. Carbon 2006, 44, 1292-1297.

97. Lacerda, L.; Pastorin, G.; Wu, W.; Prato, M.; Bianco, A.; Kostarelos, K. Luminescence of functionalized carbon nanotubes as a tool to monitor bundle formation and dissociation in water: The effect of plasmid-DNA complexation. Adv. Funct. Mater. 2006, 16, 1839-1846.

98. Asada, Y.; Dohi, H.; Kuwahara, S.; Sugai, T.; Kitaura, R.; Shinohara, H. Synthesis and spectroscopic characterization of salmon DNA-wrapped single-wall carbon nanotubes. Nano 2007, 2, 295-299.

99. Karachevtsev, V.A.; Glamazda, A.Y.; Leontiev, V.S.; Lytvyn, O.S.; Dettlaff-Weglikowska, U. Glucose sensing based on nir fluorescence of DNA-wrapped single-walled carbon nanotubes. Chem. Phys. Lett. 2007, 435, 104-108.

100. Tu, X.M.; Pehrsson, P.E.; Zhao, W. Redox reaction of DNA-encased HiPCO carbon nanotubes with hydrogen peroxide: A near infrared optical sensitivity and kinetics study. J. Phys. Chem. C 2007, 111, 17227-17231.

101. Xu, Y.; Pehrsson, P.E.; Chen, L.W.; Zhang, R.; Zhao, W. Double-stranded DNA single-walled carbon nanotube hybrids for optical hydrogen peroxide and glucose sensing. J. Phys. Chem. C 2007, 111, 8638-8643.

102. Cao, C.F.; Kim, J.H.; Yoon, D.; Hwang, E.S.; Kim, Y.J.; Baik, S. Optical detection of DNA hybridization using absorption spectra of single-walled carbon nanotubes. Mater. Chem. Phys. 2008, 112, 738-741.

103. Cathcart, H.; Nicolosi, V.; Hughes, J.M.; Blau, W.J.; Kelly, J.M.; Quinn, S.J.; Coleman, J.N. Ordered DNA wrapping switches on luminescence in single-walled nanotube dispersions. J. Am. Chem. Soc. 2008, 130, 12734-12744.

104. Qian, H.; Araujo, P.T.; Georgi, C.; Gokus, T.; Hartmann, N.; Green, A.A.; Jorio, A.; Hersam, M.C.; Novotny, L.; Hartschuh, A. Visualizing the local optical response of semiconducting carbon nanotubes to DNA-wrapping. Nano Lett. 2008, 8, 2706-2711.

105. Yoon, D.; Cao, C.; Choi, J.B.; Kim, Y.J.; Baik, S. Optical characterization of DNA-wrapped single walled carbon nanotubes irradiated with ultraviolet light. J. Nanosci. Nanotechnol. 2008, 8, 5135-5138.

106. Shoda, M.; Bandow, S.; Maruyama, Y.; Iijima, S. Probing interaction between ssDNA and carbon nanotubes by raman scattering and electron microscopy. J. Phys. Chem. C 2009, 113, 6033-6036.

107. Simpson, J.R.; Fagan, J.A.; Becker, M.L.; Hobbie, E.K.; Walker, A.R.H. The effect of dispersant on defects in length-separated single-wall carbon nanotubes measured by raman spectroscopy. Carbon 2009, 47, 3238-3241. 
108. Chen, Z.; Liu, R.; Wang, Y.L.; Zhu, H.R.; Sun, Z.P.; Zuo, T.S.; Chang, X.L.; Zhao, F.; Xing, G.M.; Yuan, H.; et al. Ag nanoparticles coated swcnt with surface enhanced raman scattering (SERS) signals. J. Nanosci. Nanotechnol. 2010, 10, 8538-8543.

109. Park, J.J.; Fagan, J.A.; Huh, J.Y.; Migler, K.B.; Karim, A.; Raghavan, D. Spr imaging study of DNA wrapped single wall carbon nanotube (ssDNA-SWCNT) adsorption on a model biological (collagen) substrate. Soft Matter 2010, 6, 5581-5588.

110. Ignatova, T.; Najafov, H.; Ryasnyanskiy, A.; Biaggio, I.; Zheng, M.; Rotkin, S.V. Significant fret between swnt/DNA and rare earth ions: A signature of their spatial correlations. ACS Nano 2011, $5,6052-6059$.

111. Shao, J.Y.; Sun, T.; Guo, Q.Y.; Li, H.; Lan, S. In situ electrochemically tuned photoluminescence of $\left[\mathrm{Ru}(\mathrm{bpy})_{2}(\mathrm{dppz})\right]^{2+}$ aggregates with single-walled carbon nanotubes and DNA monitored by guanine oxidation. Transit. Met. Chem. 2011, 36, 499-504.

112. Ensafi, A.A.; Amini, M.; Rezaei, B. Biosensor based on ds-DNA decorated chitosan modified multiwall carbon nanotubes for voltammetric biodetection of herbicide amitrole. Colloid Surf. B 2013, 109, 45-51.

113. Nii, D.; Hayashida, T.; Umemura, K. Controlling the adsorption and desorption of double-stranded DNA on functionalized carbon nanotube surface. Colloid Surf. B 2013, 106, 234-239.

114. Ozturk, S.A.; Kelestemur, S.; Culha, M. Influence of oligonucleotide interaction on electronic properties of single walled carbon nanotubes. J. Raman Spectrosc. 2013, 44, 183-189.

115. Ito, M.; Kobayashi, T.; Ito, Y.; Hayashida, T.; Nii, D.; Umemura, K.; Homma, Y. Intense photoluminescence from dried double-stranded DNA and single-walled carbon nanotube hybrid. Appl. Phys. Lett. 2014, 104, doi:10.1063/1.4863272

116. Takahashi, H.; Numao, S.; Bandow, S.; Iijima, S. Afm imaging of wrapped multiwall carbon nanotube in DNA. Chem. Phys. Lett. 2006, 418, 535-539.

117. Campbell, J.F.; Tessmer, I.; Thorp, H.H.; Erie, D.A. Atomic force microscopy studies of DNA-wrapped carbon nanotube structure and binding to quantum dots. J. Am. Chem. Soc. 2008, 130, 10648-10655.

118. Toita, S.; Kang, D.; Kobayashi, K.; Kawamoto, H.; Kojima, K.; Tachibana, A. Atomic force microscopic study on DNA-wrapping for different diameter single-wall carbon nanotubes. Diam. Relat. Mater. 2008, 17, 1389-1393.

119. Xu, Y.Q.; Barnard, A.; McEuen, P.L. Bending and twisting of suspended single-walled carbon nanotubes in solution. Nano Lett. 2009, 9, 1609-1614.

120. Arnett, C.M.; Marsh, C.P.; Welch, C.R.; Strano, M.S.; Han, J.H.; Gray, J.H.; Carlson, T.A. Enzyme-mediated assimilation of DNA-functionalized single-walled carbon nanotubes. Langmuir 2010, 26, 613-617.

121. Hayashida, T.; Kawashima, T.; Nii, D.; Ozasa, K.; Umemura, K. Kelvin probe force microscopy of single-walled carbon nanotubes modified with DNA or poly(ethylene glycol). Chem. Lett. 2013, 42, 666-668.

122. Hayashida, T.; Umemura, K. Surface morphology of hybrids of double-stranded DNA and single-walled carbon nanotubes studied by atomic force microscopy. Colloid Surf. B 2013, 101, 49-54. 
123. Nii, D.; Hayashida, T.; Yamaguchi, Y.; Ikawa, S.; Shibata, T.; Umemura, K. Selective binding of single-stranded DNA-binding proteins onto DNA molecules adsorbed on single-walled carbon nanotubes. Colloid Surf. B 2014, 121, 325-330.

124. Iijima, M.; Watabe, T.; Ishii, S.; Koshio, A.; Yamaguchi, T.; Bandow, S.; Iijima, S.; Suzuki, K.; Maruyama, Y. Fabrication and STM-characterization of novel hybrid materials of DNA/carbon nanotube. Chem. Phys. Lett. 2005, 414, 520-524.

125. Karachevtsev, M.V.; Lytvyn, O.S.; Stepanian, S.G.; Leontiev, V.S.; Adamowicz, L.; Karachevtsev, V.A. SWNT-DNA and SWNT-polyC hybrids: AFM study and computer modeling. J. Nanosci. Nanotechnol. 2008, 8, 1473-1480.

126. Lulevich, V.; Kim, S.; Grigoropoulos, C.P.; Noy, A. Frictionless sliding of single-stranded DNA in a carbon nanotube pore observed by single molecule force spectroscopy. Nano Lett. 2011, 11, 1171-1176.

127. Rao, R.; Lee, J.; Lu, Q.; Keskar, G.; Freedman, K.O.; Floyd, W.C.; Rao, A.M.; Ke, P.C. Single-molecule fluorescence microscopy and raman spectroscopy studies of RNA bound carbon nanotubes. Appl. Phys. Lett. 2004, 85, 4228-4230.

128. Yang, R.H.; Jin, J.Y.; Chen, Y.; Shao, N.; Kang, H.Z.; Xiao, Z.; Tang, Z.W.; Wu, Y.R.; Zhu, Z.; Tan, W.H. Carbon nanotube-quenched fluorescent oligonucleotides: Probes that fluoresce upon hybridization. J. Am. Chem. Soc. 2008, 130, 8351-8358.

129. Zhang, L.B.; Tao, L.; Li, B.L.; Jing, L.; Wang, E.K. Carbon nanotube-DNA hybrid fluorescent sensor for sensitive and selective detection of mercury(II) ion. Chem. Commun. 2010, 46, 1476-1478.

130. Zhao, C.; Qu, K.G.; Song, Y.J.; Xu, C.; Ren, J.S.; Qu, X.G. A reusable DNA single-walled carbon-nanotube-based fluorescent sensor for highly sensitive and selective detection of $\mathrm{Ag}+$ and cysteine in aqueous solutions. Chemistry 2010, 16, 8147-8154.

131. D’Souza, F.; Das, S.K.; Zandler, M.E.; Sandanayaka, A.S.D.; Ito, O. Bionano donor-acceptor hybrids of porphyrin, ssDNA, and semiconductive single-wall carbon nanotubes for electron transfer via porphyrin excitation. J. Am. Chem. Soc. 2011, 133, 19922-19930.

132. Qin, W.L.; Yang, K.Q.; Tang, H.; Tan, L.A.; Xie, Q.J.; Ma, M.; Zhang, Y.Y.; Yao, S.Z. Improved GFP gene transfection mediated by polyamidoamine dendrimer-functionalized multi-walled carbon nanotubes with high biocompatibility. Colloid Surf. B 2011, 84, 206-213.

133. Zhang, J.Q.; Boghossian, A.A.; Barone, P.W.; Rwei, A.; Kim, J.H.; Lin, D.H.; Heller, D.A.; Hilmer, A.J.; Nair, N.; Reuel, N.F.; et al. Single molecule detection of nitric oxide enabled by $\mathrm{d}(\mathrm{AT})(15)$ DNA adsorbed to near infrared fluorescent single-walled carbon nanotubes. J. Am. Chem. Soc. 2011, 133, 567-581.

134. Martinez, M.T.; Tseng, Y.C.; Gonzalez, M.; Bokor, J. Streptavidin as cnts and DNA linker for the specific electronic and optical detection of DNA hybridization. J. Phys. Chem. C 2012, 116, 22579-22586.

135. Wang, L.Y.; Cheng, Y.Q.; Wang, H.; Li, Z.P. A homogeneous fluorescence sensing platform with water-soluble carbon nanoparticles for detection of microrna and nuclease activity. Analyst 2012, 137, 3667-3672. 
136. Bergler, F.F.; Schoppler, F.; Brunecker, F.K.; Hailman, M.; Hertel, T. Fluorescence spectroscopy of gel-immobilized single-wall carbon nanotubes with microfluidic control of the surfactant environment. J. Phys. Chem. C 2013, 117, 13318-13323.

137. Judkins, J.; Lee, H.H.; Tung, S.; Kim, J.W. Diffusion of single-walled carbon nanotube under physiological conditions. J. Biomed. Nanotechnol. 2013, 9, 1065-1070.

138. Hazani, M.; Naaman, R.; Hennrich, F.; Kappes, M.M. Confocal fluorescence imaging of DNA-functionalized carbon nanotubes. Nano Lett. 2003, 3, 153-155.

139. Stevens, J.L.; Huang, A.Y.; Peng, H.Q.; Chiang, L.W.; Khabashesku, V.N.; Margrave, J.L. Sidewall amino-functionalization of single-walled carbon nanotubes through fluorination and subsequent reactions with terminal diamines. Nano Lett. 2003, 3, 331-336.

140. Jung, D.H.; Kim, B.H.; Ko, Y.K.; Jung, M.S.; Jung, S.; Lee, S.Y.; Jung, H.T. Covalent attachment and hybridization of DNA oligonucleotides on patterned single-walled carbon nanotube films. Langmuir 2004, 20, 8886-8891.

141. Singh, K.V.; Pandey, R.R.; Wang, X.; Lake, R.; Ozkan, C.S.; Wang, K.; Ozkan, M. Covalent functionalization of single walled carbon nanotubes with peptide nucleic acid: Nanocomponents for molecular level electronics. Carbon 2006, 44, 1730-1739.

142. Wang, X.; Liu, F.; Andavan, G.T.S.; Jing, X.Y.; Singh, K.; Yazdanpanah, V.R.; Bruque, N.; Pandey, R.R.; Lake, R.; Ozkan, M.; et al. Carbon nanotube-DNA nanoarchitectures and electronic functionality. Small 2006, 2, 1356-1365.

143. Yuan, W.K.; Wu, H.; Jiang, Z.Y.; Xu, S.W. Covalent functionalization of carbon nanotubes. Chin. J. Org. Chem. 2006, 26, 1508-1517.

144. Yang, W.R.; Moghaddam, M.J.; Taylor, S.; Bojarski, B.; Wieczorek, L.; Herrmann, J.; McCall, M.J. Single-walled carbon nanotubes with DNA recognition. Chem. Phys. Lett. 2007, 443, 169-172.

145. Moghaddam, M.J.; Yang, W.R.; Bojarski, B.; Gengenbach, T.R.; Gao, M.; Zareie, H.; McCall, M.J. Azide photochemistry for facile modification of graphitic surfaces: Preparation of DNA-coated carbon nanotubes for biosensing. Nanotechnology 2012, doi:10.1088/0957-4484/23/42/425503.

146. Alidori, S.; Asqiriba, K.; Londero, P.; Bergkvist, M.; Leona, M.; Scheinberg, D.A.; McDevitt, M.R. Deploying rna and DNA with functionalized carbon nanotubes. J. Phys. Chem. C 2013, 117, 5982-5992.

147. Dolash, B.D.; Lahiji, R.R.; Zemlyanov, D.Y.; Drachev, V.P.; Reifenberger, R.; Bergstrom, D.E. Sonication mediated covalent cross-linking of DNA to single-walled carbon nanotubes. Chem. Phys. 2013, 413, 11-19.

148. Singh, P.; Menard-Moyon, C.; Battigelli, A.; Toma, F.M.; Raya, J.; Kumar, J.; Nidamanuri, N.; Verma, S.; Bianco, A. Double functionalization of carbon nanotubes with purine and pyrimidine derivatives. Chemistry 2013, 8, 1472-1481.

149. Canete-Rosales, P.; Gonzalez, M.; Anson, A.; Martinez, M.T.; Yanez, C.; Bollo, S. Electrochemical characterization of oligonucleotide-carbon nanotube functionalized using different strategies. Electrochim. Acta 2014, 140, 489-496.

150. Kaufmann, A.; Kunhardt, D.; Cirillo, G.; Hampel, S.; Schwenzer, B. Functionalized carbon nanotubes as transporters for antisense oligodeoxynucleotides. J. Mater. Chem. B 2014, 2, $7000-7008$. 
151. Gao, H.J.; Kong, Y.; Cui, D.X.; Ozkan, C.S. Spontaneous insertion of DNA oligonucleotides into carbon nanotubes. Nano Lett. 2003, 3, 471-473.

152. Okada, T.; Kaneko, T.; Hatakeyama, R. Single-stranded DNA insertion into single-walled carbon nanotubes by ion irradiation in an electrolyte plasma. Jpn. J. Appl. Phys. Part 1 Regul. Pap. Brief Commun. Rev. Pap. 2006, 45, 8335-8339.

153. Okada, T.; Kaneko, T.; Hatakeyama, R.; Tohji, K. Electrically triggered insertion of single-stranded DNA into single-walled carbon nanotubes. Chem. Phys. Lett. 2006, 417, 288-292.

154. Kaneko, T.; Okada, T.; Hatakeyama, R. DNA encapsulation inside carbon nanotubes using micro electrolyte plasmas. Contrib. Plasma Phys. 2007, 47, 57-63.

155. Pei, Q.X.; Lim, C.G.; Cheng, Y.; Gao, H.J. Molecular dynamics study on DNA oligonucleotide translocation through carbon nanotubes. J. Chem. Phys. 2008, 129, doi:10.1063/1.2981798.

156. Zimmerli, U.; Koumoutsakos, P. Simulations of electrophoretic rna transport through transmembrane carbon nanotubes. Biophys. J. 2008, 94, 2546-2557.

157. Kamiya, K.; Okada, S. Energetics and electronic structure of encapsulated single-stranded DNA in carbon nanotubes. Phys. Rev. B 2011, 83, doi:10.1103/PhysRevB.83.155444.

158. Enyashin, A.N.; Gemming, S.; Seifert, G. DNA-wrapped carbon nanotubes. Nanotechnology 2007, 18, doi:10.1088/0957-4484/18/24/245702.

159. Frischknecht, A.L.; Martin, M.G. Simulation of the adsorption of nucleotide monophosphates on carbon nanotubes in aqueous solution. J. Phys. Chem. C 2008, 112, 6271-6278.

160. Zheng, M.; Eom, K.; Ke, C.H. Calculations of the resonant response of carbon nanotubes to binding of DNA. J. Phys. D 2009, 42, 8.

161. Bobadilla, A.D.; Seminario, J.M. DNA-CNT interactions and gating mechanism using MD and DFT. J. Phys. Chem. C 2011, 115, 3466-3474.

162. Ding, Z.J.; Jiao, Y.; Meng, S. Quantum simulation of molecular interaction and dynamics at surfaces. Front. Phys. 2011, 6, 294-308.

163. Makarucha, A.J.; Todorova, N.; Yarovsky, I. Nanomaterials in biological environment: A review of computer modelling studies. Eur. Biophys. J. Biophys. Lett. 2011, 40, 103-115.

164. Roxbury, D.; Jagota, A.; Mittal, J. Sequence-specific self-stitching motif of short single-stranded DNA on a single-walled carbon nanotube. J. Am. Chem. Soc. 2011, 133, 13545-13550.

165. Umadevi, D.; Sastry, G.N. Quantum mechanical study of physisorption of nucleobases on carbon materials: Graphene versus carbon nanotubes. J. Phys. Chem. Lett. 2011, 2, 1572-1576.

166. Xiao, Z.T.; Wang, X.; Xu, X.; Zhang, H.; Li, Y.; Wang, Y.H. Base- and structure-dependent DNA dinucleotide-carbon nanotube interactions: Molecular dynamics simulations and thermodynamic analysis. J. Phys. Chem. C 2011, 115, 21546-21558.

167. Akdim, B.; Pachter, R.; Day, P.N.; Kim, S.S.; Naik, R.R. On modeling biomolecular-surface nonbonded interactions: Application to nucleobase adsorption on single-wall carbon nanotube surfaces. Nanotechnology 2012, 23, doi:10.1088/0957-4484/23/16/165703.

168. Alegret, N.; Santos, E.; Rodriguez-Fortea, A.; Rius, F.X.; Poblet, J.M. Disruption of small double stranded DNA molecules on carbon nanotubes: A molecular dynamics study. Chem. Phys. Lett. 2012, 525-526, 120-124.

169. Roxbury, D.; Mittal, J.; Jagota, A. Molecular-basis of single-walled carbon nanotube recognition by single-stranded DNA. Nano Lett. 2012, 12, 1464-1469. 
170. Santosh, M.; Panigrahi, S.; Bhattacharyya, D.; Sood, A.K.; Maiti, P.K. Unzipping and binding of small interfering RNA with single walled carbon nanotube: A platform for small interfering RNA delivery. J. Chem. Phys. 2012, 136, doi:10.1063/1.3682780.

171. Yamazaki, T.; Fenniri, H. Imaging carbon nanotube interaction with nucleobases in water using the statistical mechanical theory of molecular liquids. J. Phys. Chem. C 2012, 116, 15087-15092.

172. Amirani, M.C.; Tang, T.; Cuervo, J. Quantum mechanical treatment of binding energy between DNA nucleobases and carbon nanotube: A DFT analysis. Physica E 2013, 54, 65-71.

173. Clavier, A.; Kraszewski, S.; Ramseyer, C.; Picaud, F. Insertion kinetics of small nucleotides through single walled carbon nanotube. J. Biotechnol. 2013, 164, 13-18.

174. Wu, N.; Wang, Q.; Pang, S.S. Dispersion of a bundle of carbon nanotubes by mechanical torsional energy. Carbon 2013, 59, 229-236.

175. Ostojic, G.N.; Ireland, J.R.; Hersam, M.C. Noncovalent functionalization of DNA-wrapped single-walled carbon nanotubes with platinum-based DNA cross-linkers. Langmuir 2008, 24, 9784-9789.

176. Zhang, L.; Huang, C.Z.; Li, Y.F.; Xiao, S.J.; Xie, J.P. Label-free detection of sequence-specific DNA with multiwalled carbon nanotubes and their light scattering signals. J. Phys. Chem. B 2008, 112, 7120-7122.

177. Zhou, Z.P.; Kang, H.; Clarke, M.L.; Lacerda, S.H.D.; Zhao, M.H.; Fagan, J.A.; Shapiro, A.; Nguyen, T.; Hwang, J. Water-soluble DNA-wrapped single-walled carbon-nanotuble/quantum-dot complexes. Small 2009, 5, 2149-2155.

178. Campbell, J.F.; Napier, M.E.; Feldberg, S.W.; Thorp, H.H. Metal-mediated electrochemical oxidation of DNA-wrapped carbon nanotubes. J. Phys. Chem. B 2010, 114, 8861-8870.

179. Weizmann, Y.; Chenoweth, D.M.; Swager, T.M. Addressable terminally linked DNA-CNT nanowires. J. Am. Chem. Soc. 2010, 132, 14009-14011.

180. Aravind, S.S.J.; Ramaprabhu, S. Noble metal dispersed multiwalled carbon nanotubes immobilized ss-DNA for selective detection of dopamine. Sens. Actuator B 2011, 155, 679-686.

181. Asada, Y.; Miyata, Y.; Shiozawa, K.; Ohno, Y.; Kitaura, R.; Mizutani, T.; Shinohara, H. Thin-film transistors with length-sorted DNA-wrapped single-wall carbon nanotubes. J. Phys. Chem. C 2011, $115,270-273$.

182. Cao, S.R.; Wang, J.F.; Yuan, R.; Chai, Y.Q. An amperometric immunoassay for human chorionic gonadotrophin based on DNA-multiwalled carbon nanotubes and methylene blue as sensing interface. Sens. Lett. 2011, 9, 1636-1642.

183. Fujigaya, T.; Yamamoto, Y.; Kano, A.; Maruyama, A.; Nakashima, N. Enhanced cell uptake via non-covalent decollation of a single-walled carbon nanotube-DNA hybrid with polyethylene glycol-grafted poly(l-lysine) labeled with an alexa-dye and its efficient uptake in a cancer cell. Nanoscale 2011, 3, 4352-4358.

184. Guo, Q.Y.; Shao, J.Y.; Sun, T.; Li, H.; Lan, S.; Xu, Z.H. Electrochemical fabrication and potential-enhanced luminescence of $\left[\mathrm{Ru}(\mathrm{bpy})_{2} \text { tatp }\right]^{2+}$ incorporating DNA-stabilized single-wall carbon nanotubes on an indium tin oxide electrode. Electrochim. Acta 2011, 56, 1432-1438.

185. Shi, J.; Cha, T.G.; Claussen, J.C.; Diggs, A.R.; Choi, J.H.; Porterfield, D.M. Microbiosensors based on DNA modified single-walled carbon nanotube and Pt black nanocomposites. Analyst 2011, 136, 4916-4924. 
186. Han, S.P.; Maune, H.T.; Barish, R.D.; Bockrath, M.; Goddard, W.A. DNA-linker-induced surface assembly of ultra dense parallel single walled carbon nanotube arrays. Nano Lett. 2012, 12, 1129-1135.

187. Kawaguchi, M.; Yamazaki, J.; Ohno, J.; Fukushima, T. Preparation and binding study of a complex made of DNA-treated single-walled carbon nanotubes and antibody for specific delivery of a "molecular heater" platform. Int. J. Nanomed. 2012, 7, 4363-4371.

188. Shin, S.R.; Lee, C.K.; Eom, T.W.; Lee, S.H.; Kwon, C.H.; So, I.; Kim, S.J. DNA-coated MWNT microfibers for electrochemical actuator. Sens. Actuator B 2012, 162, 173-177.

189. Thuy, N.T.; Tam, P.D.; Tuan, M.A.; Le, A.T.; Tam, L.T.; Thu, V.V.; Hieu, N.V.; Chien, N.D. Detection of pathogenic microorganisms using biosensor based on multi-walled carbon nanotubes dispersed in DNA solution. Curr. Appl. Phys. 2012, 12, 1553-1560.

190. Yu, T.; Gong, Y.X.; Lu, T.T.; Wei, L.; Li, Y.Q.; Mu, Y.G.; Chen, Y.; Liao, K. Recognition of carbon nanotube chirality by phage display. RSC Adv. 2012, 2, 1466-1476.

191. Zhang, L.Y.; Guo, C.X.; Cui, Z.M.; Guo, J.; Dong, Z.L.; Li, C.M. DNA-directed growth of Pd nanocrystals on carbon nanotubes towards efficient oxygen reduction reactions. Chemistry 2012, $18,15693-15698$.

192. Gong, J.L.; Sarkar, T.; Badhulika, S.; Mulchandani, A. Label-free chemiresistive biosensor for mercury (II) based on single-walled carbon nanotubes and structure-switching DNA. Appl. Phys. Lett. 2013, 102, doi:10.1063/1.4773569.

193. Mangalum, A.; Rahman, M.; Norton, M.L. Site-specific immobilization of single-walled carbon nanotubes onto single and one-dimensional DNA origami. J. Am. Chem. Soc. 2013, 135, 2451-2454.

194. Sha, J.J.; Hasan, T.; Milana, S.; Bertulli, C.; Bell, N.A.W.; Privitera, G.; Ni, Z.H.; Chen, Y.F.; Bonaccorso, F.; Ferrari, A.C.; et al. Nanotubes complexed with DNA and proteins for resistive-pulse sensing. ACS Nano 2013, 7, 8857-8869.

195. Su, H.C.; Zhang, M.L.; Bosze, W.; Lim, J.H.; Myung, N.V. Metal nanoparticles and DNA co-functionalized single-walled carbon nanotube gas sensors. Nanotechnology 2013, 24, doi:10.1088/0957-4484/24/50/505502.

196. Gong, X.; Sharma, A.K.; Strano, M.S.; Mukhopadhyay, D. Selective assembly of DNA-conjugated single-walled carbon nanotubes from the vascular secretome. ACS Nano 2014, 8, 9126-9136.

197. Guo, C.X.; Chitre, A.A.; Lu, X.M. DNA-assisted assembly of carbon nanotubes and $\mathrm{MnO} 2$ nanospheres as electrodes for high-performance asymmetric supercapacitors. Phys. Chem. Chem. Phys. 2014, 16, 4672-4678.

198. Tardani, F.; Pucci, C.; La Mesa, C. Confining ss-DNA/carbon nanotube complexes in ordered droplets. Soft Matter 2014, 10, 1024-1031.

199. Tardani, F.; Sennato, S. Phase behavior of DNA-stabilized carbon nanotubes dispersions: Association with oppositely-charged additives. J. Phys. Chem. C 2014, 118, 9268-9274.

200. Williams, R.M.; Nayeem, S.; Dolash, B.D.; Sooter, L.J. The effect of DNA-dispersed single-walled carbon nanotubes on the polymerase chain reaction. PLoS One 2014, 9, doi:10.1371/journal.pone.0094117. 
201. Gowtham, S.; Scheicher, R.H.; Ahuja, R.; Pandey, R.; Karna, S.P. Physisorption of nucleobases on graphene: Density-functional calculations. Phys. Rev. B 2007, 76, doi:10.1103/PhysRevB.76.033401.

202. Varghese, N.; Mogera, U.; Govindaraj, A.; Das, A.; Maiti, P.K.; Sood, A.K.; Rao, C.N.R. Binding of DNA nucleobases and nucleosides with graphene. ChemPhysChem 2009, 10, 206-210.

203. He, S.J.; Song, B.; Li, D.; Zhu, C.F.; Qi, W.P.; Wen, Y.Q.; Wang, L.H.; Song, S.P.; Fang, H.P.; Fan, C.H. A graphene nanoprobe for rapid, sensitive, and multicolor fluorescent DNA analysis. $A d v$. Funct. Mater. 2010, 20, 453-459.

204. Liu, F.; Choi, J.Y.; Seo, T.S. DNA mediated water-dispersible graphene fabrication and gold nanoparticle-graphene hybrid. Chem. Commun. 2010, 46, 2844-2846.

205. Liu, J.B.; Li, Y.L.; Li, Y.M.; Li, J.H.; Deng, Z.X. Noncovalent DNA decorations of graphene oxide and reduced graphene oxide toward water-soluble metal-carbon hybrid nanostructures via self-assembly. J. Mater. Chem. 2010, 20, 900-906.

206. Lv, W.; Guo, M.; Liang, M.H.; Jin, F.M.; Cui, L.; Zhi, L.J.; Yang, Q.H. Graphene-DNA hybrids: Self-assembly and electrochemical detection performance. J. Mater. Chem. 2010, 20, 6668-6673.

207. Zhang, Q.A.; Qiao, Y.; Hao, F.; Zhang, L.; Wu, S.Y.; Li, Y.; Li, J.H.; Song, X.M. Fabrication of a biocompatible and conductive platform based on a single-stranded DNA/graphene nanocomposite for direct electrochemistry and electrocatalysis. Chemistry 2010, 16, 8133-8139.

208. Tang, L.H.; Wang, Y.; Liu, Y.; Li, J.H. DNA-directed self-assembly of graphene oxide with applications to ultrasensitive oligonucleotide assay. ACS Nano 2011, 5, 3817-3822.

209. Wei, L.L.; Borowiec, J.; Zhu, L.H.; Zhang, J.D. Electrochemical sensor for monitoring the photodegradation of catechol based on DNA-modified graphene oxide. Microchim. Acta 2011, 173, 439-443.

210. Wu, M.; Kempaiah, R.; Huang, P.J.J.; Maheshwari, V.; Liu, J.W. Adsorption and desorption of DNA on graphene oxide studied by fluorescently labeled oligonucleotides. Langmuir 2011, 27, 2731-2738.

211. Zhao, X.C. Self-assembly of DNA segments on graphene and carbon nanotube arrays in aqueous solution: A molecular simulation study. J. Phys. Chem. C 2011, 115, 6181-6189.

212. Kabelac, M.; Kroutil, O.; Predota, M.; Lankas, F.; Sip, M. Influence of a charged graphene surface on the orientation and conformation of covalently attached oligonucleotides: A molecular dynamics study. Phys. Chem. Chem. Phys. 2012, 14, 4217-4229.

213. Le, D.; Kara, A.; Schroder, E.; Hyldgaard, P.; Rahman, T.S. Physisorption of nucleobases on graphene: A comparative van der waals study. J. Phys. Condes. Matter 2012, 24, doi:10.1088/0953-8984/24/42/424210.

214. Premkumar, T.; Geckeler, K.E. Graphene-DNA hybrid materials: Assembly, applications, and prospects. Prog. Polym. Sci. 2012, 37, 515-529.

215. Qu, K.G.; Wu, L.; Ren, J.S.; Qu, X.G. Natural DNA-modified graphene/pd nanoparticles as highly active catalyst for formic acid electro-oxidation and for the Suzuki reaction. ACS Appl. Mater. Interfaces 2012, 4, 5001-5009.

216. Manna, A.K.; Pati, S.K. Theoretical understanding of single-stranded DNA assisted dispersion of graphene. J. Mat. Chem. B 2013, 1, 91-100. 
217. Zhang, X.; Gao, F.; Cai, X.L.; Zheng, M.X.; Gao, F.; Jiang, S.L.; Wang, Q.X. Application of graphene-pyrenebutyric acid nanocomposite as probe oligonucleotide immobilization platform in a DNA biosensor. Mater. Sci. Eng. C 2013, 33, 3851-3857.

218. Joseph, D.; Seo, S.; Williams, D.R.; Geckeer, K.E. Double-stranded DNA-graphene hybrid: Preparation and anti-proliferative activity. ACS Appl. Mater. Interfaces 2014, 6, 3347-3356.

219. Shekar, S.C.; Swathi, R.S. Stability of nucleobases and base pairs adsorbed on graphyne and graphdiyne. J. Phys. Chem. C 2014, 118, 4516-4528.

220. Belyanskaya, L.; Weigel, S.; Hirsch, C.; Tobler, U.; Krug, H.F.; Wick, P. Effects of carbon nanotubes on primary neurons and glial cells. Neurotoxicology 2009, 30, 702-711.

221. Deng, X.Y.; Wu, F.; Liu, Z.; Luo, M.; Li, L.; Ni, Q.S.; Jiao, Z.; Wu, M.H.; Liu, Y.F. The splenic toxicity of water soluble multi-walled carbon nanotubes in mice. Carbon 2009, 47, 1421-1428.

222. Folkmann, J.K.; Risom, L.; Jacobsen, N.R.; Wallin, H.; Loft, S.; Moller, P. Oxidatively damaged DNA in rats exposed by oral gavage to $\mathrm{C} 60$ fullerenes and single-walled carbon nanotubes. Environ. Health Perspect. 2009, 117, 703-708.

223. Antonelli, A.; Serafini, S.; Menotta, M.; Sfara, C.; Pierige, F.; Giorgi, L.; Ambrosi, G.; Rossi, L.; Magnani, M. Improved cellular uptake of functionalized single-walled carbon nanotubes. Nanotechnology 2010, 21, doi:10.1088/0957-4484/21/42/425101.

224. Asakura, M.; Sasaki, T.; Sugiyama, T.; Takaya, M.; Koda, S.; Nagano, K.; Arito, H.; Fukushima, S. Genotoxicity and cytotoxicity of multi-wall carbon nanotubes in cultured chinese hamster lung cells in comparison with chrysotile a fibers. J. Occup. Health 2010, 52, 155-166.

225. Cveticanin, J.; Joksic, G.; Leskovac, A.; Petrovic, S.; Sobot, A.V.; Neskovic, O. Using carbon nanotubes to induce micronuclei and double strand breaks of the DNA in human cells. Nanotechnology 2010, 21, doi:10.1088/0957-4484/21/1/015102.

226. Lima, A.; Melo, A.M.D.; Pires, E.V.; Ferreira, R.C.D.; Sant'Ana, A.E.G.; Goulart, M.O.F.; de Abreu, F.C. Electroanalytical studies of sulfentrazone in protic medium, its degradation by the electro-fenton process, and toxicity assessment using ss-DNA. Chemosphere 2010, 81, 884-889.

227. Luszczyn, J.; Plonska-Brzezinska, M.E.; Palkar, A.; Dubis, A.T.; Simionescu, A.; Simionescu, D.T.; Kalska-Szostko, B.; Winkler, K.; Echegoyen, L. Small noncytotoxic carbon nano-onions: First covalent functionalization with biomolecules. Chemistry 2010, 16, 4870-4880.

228. Raffa, V.; Ciofani, G.; Vittorio, O.; Riggio, C.; Cuschieri, A. Physicochemical properties affecting cellular uptake of carbon nanotubes. Nanomedicine 2010, 5, 89-97.

229. Sabuncu, A.C.; Kalluri, B.S.; Qian, S.Z.; Stacey, M.W.; Beskok, A. Dispersion state and toxicity of mwCNTs in cell culture medium with different T80 concentrations. Colloid Surf. B 2010, 78, 36-43.

230. Shen, C.X.; Zhang, Q.F.; Li, J.A.; Bi, F.C.; Yao, N. Induction of programmed cell death in arabidopsis and rice by single-wall carbon nanotubes. Am. J. Bot. 2010, 97, 1602-1609.

231. Nam, C.W.; Kang, S.J.; Kang, Y.K.; Kwak, M.K. Cell growth inhibition and apoptosis by sds-solubilized single-walled carbon nanotubes in normal rat kidney epithelial cells. Arch. Pharm. Res. 2011, 34, 661-669.

232. Dong, P.X.; Wan, B.; Guo, L.H. In vitro toxicity of acid-functionalized single-walled carbon nanotubes: Effects on murine macrophages and gene expression profiling. Nanotoxicology 2012, 6, 288-303. 
233. Handy, R.D.; van den Brink, N.; Chappell, M.; Muhling, M.; Behra, R.; Dusinska, M.; Simpson, P.; Ahtiainen, J.; Jha, A.N.; Seiter, J.; et al. Practical considerations for conducting ecotoxicity test methods with manufactured nanomaterials: What have we learnt so far? Ecotoxicology 2012, 21, 933-972.

234. Kim, J.S.; Sung, J.H.; Song, K.S.; Lee, J.H.; Kim, S.M.; Lee, G.H.; Ahn, K.H.; Lee, J.S.; Shin, J.H.; Park, J.D.; et al. Persistent DNA damage measured by comet assay of sprague dawley rat lung cells after five days of inhalation exposure and 1 month post-exposure to dispersed multi-wall carbon nanotubes (MWCNTs) generated by new MWCNT aerosol generation system. Toxicol. Sci. 2012, $128,439-448$.

235. Mogurampelly, S.; Panigrahi, S.; Bhattacharyya, D.; Sood, A.K.; Maiti, P.K. Unraveling siRNA unzipping kinetics with graphene. J. Chem. Phys. 2012, 137, doi:10.1063/1.4742189.

236. Van Berlo, D.; Clift, M.; Albrecht, C.; Schins, R. Carbon nanotubes: An insight into the mechanisms of their potential genotoxicity. Swiss Med. Wkly. 2012, 142, doi:10.4414/smw.2012.13698.

237. Awasthi, K.K.; John, P.J.; Awasthi, A.; Awasthi, K. Multi walled carbon nano tubes induced hepatotoxicity in Swiss albino mice. Micron 2013, 44, 359-364.

238. Mao, H.L.; Kawazoe, N.; Chen, G.P. Uptake and intracellular distribution of collagen-functionalized single-walled carbon nanotubes. Biomaterials 2013, 34, 2472-2479.

239. Zhang, Y.L.; Deng, J.J.; Zhang, Y.X.; Guo, F.; Li, C.G.; Zou, Z.; Xi, W.; Tang, J.; Sun, Y.; Yang, P.; et al. Functionalized single-walled carbon nanotubes cause reversible acute lung injury and induce fibrosis in mice. J. Mol. Med. 2013, 91, 117-128.

240. Chen, W.; Xiong, Q.; Ren, Q.X.; Guo, Y.K.; Li, G. Can amino-functionalized carbon nanotubes carry functional nerve growth factor? Neural Regen. Res. 2014, 9, 285-292.

241. Clichici, S.; Biris, A.R.; Catoi, C.; Filip, A.; Tabaran, F. Short-term splenic impact of single-strand DNA functionalized multi-walled carbon nanotubes intraperitoneally injected in rats. J. Appl. Toxicol. 2014, 34, 332-344.

242. Hu, C.W.; Zhang, L.J.; Wang, W.L.; Cui, Y.B.; Li, M. Evaluation of the combined toxicity of multi-walled carbon nanotubes and sodium pentachlorophenate on the earthworm Eisenia fetida using avoidance bioassay and comet assay. Soil Biol. Biochem. 2014, 70, 123-130.

243. Liu, Z.B.; Liu, Y.F.; Peng, D.M. Hydroxylation of multi-walled carbon nanotubes reduces their cytotoxicity by limiting the activation of mitochondrial mediated apoptotic pathway. J. Mater. Sci. Mater. Med. 2014, 25, 1033-1044.

244. McShan, D.; Yu, H.T. DNA damage in human skin keratinocytes caused by multiwalled carbon nanotubes with carboxylate functionalization. Toxicol. Ind. Health 2014, 30, 489-498.

245. Tavares, A.M.; Louro, H.; Antunes, S.; Quarre, S.; Simar, S.; de Temmerman, P.J.; Verleysen, E.; Mast, J.; Jensen, K.A.; Norppa, H.; et al. Genotoxicity evaluation of nanosized titanium dioxide, synthetic amorphous silica and multi-walled carbon nanotubes in human lymphocytes. Toxicol. Vitro 2014, 28, 60-69.

(C) 2015 by the author; licensee MDPI, Basel, Switzerland. This article is an open access article distributed under the terms and conditions of the Creative Commons Attribution license (http://creativecommons.org/licenses/by/4.0/). 